\title{
Climate and base-level controlled fluvial system change and incision during the last glacial-interglacial transition, Roer river, the Netherlands - western Germany
}

\section{Kasse ${ }^{1, *}$, R.T. Van Balen ${ }^{1,2}$, S.J.P. Bohncke ${ }^{1}$, J. Wallinga ${ }^{3}$ \& M. Vreugdenhil ${ }^{4}$}

1 Faculty of Earth and Life Sciences, Vrije Universiteit Amsterdam, The Netherlands

2 TNO-Geological Survey of the Netherlands, Princetonlaan 6, 3584 CB Utrecht, The Netherlands

3 Soil Geography and Landscape group, Wageningen University, P.0. Box 47, 6700 AA Wageningen, The Netherlands

4 Centre for Water Resource Systems, TU Wien, Karlsplatz 13/222, A-1040 Vienna, Austria

* Corresponding author. Email: c.kasse@vu.nl

Manuscript received: 23 March 2016, accepted: 8 November 2016

\section{Abstract}

The fluvial development of the Roer river in the southeastern Netherlands and western Germany is presented for the Late Pleniglacial, Late-glacial and Early Holocene periods. Reconstruction of fluvial-style changes is based on geomorphological and sedimentological analysis. Time control comes from correlation to the pollen-based biochronostratigraphic framework of the Netherlands combined with independent optically stimulated luminescence (OSL) ages. At the Pleniglacial to Late-glacial transition a system and channel pattern change occurred from an aggrading braided to an incising meandering system. Rapid rates of meander migration, as established for the Late-glacial by optical dating, were likely related to the sandy nature of the substratum and the Late-glacial incision of the Meuse that resulted in a higher river gradient in the downstream part of the Roer. In the Roer valley the Younger Dryas cooling is not clearly reflected by a fluvial system response, but this may also be related to Holocene erosion of Younger Dryas fluvial forms. An important incision and terrace formation was established at the Younger Dryas to Early Holocene transition, probably related to forest recovery, reduced sediment supply and base-level lowering of the Meuse. The results of this study show a stepwise reduction in the number of channel courses from a multi-channel braided system in the Pleniglacial, to a double meander-belt system in the Late-glacial and a single-channel meandering system in the Early Holocene. The results show that the forcing factors of fluvial-system change in the Roer valley are climate change (precipitation, permafrost and vegetation) and downstream base-level control by the Meuse.

Keywords: fluvial response, Late-glacial, meandering river, OSL dating, terraces, vegetation

\section{Introduction}

The relation(s) between fluvial systems and climate and vegetation for the Late-glacial and Early Holocene have long been studied in the Netherlands (Pons, 1957; Van den Broek \& Maarleveld, 1963; Berendsen et al., 1995; Kasse et al., 1995; Huisink, 1997; Tebbens et al., 1999; Van Huissteden \& Kasse, 2001; Cohen et al., 2002; Cohen, 2003; Busschers et al., 2007; Hij-ma et al., 2009; Erkens et al., 2011; Janssens et al., 2012; Zuidhoff \& Huizer, 2015). In these studies braided systems are correlated to cold periods, whereas meandering systems are mostly connected to interstadial and interglacial conditions. The Meuse river and Meuse-Niers-Rhine confluence area between
Roermond and Nijmegen revealed an especially strong connection between climate, channel planform changes and phases of instability as demonstrated by incision and terrace formation (Pons, 1957; Berendsen et al., 1995; Kasse et al., 1995; Huisink, 1997; Tebbens et al., 1999). Subsequently, river systems in Poland, Germany and Hungary have been investigated in order to establish whether the changes to those systems were similar and synchronous to those documented in the Netherlands, to determine local (vegetation, tectonics) or regional climate forcing (Vandenberghe et al., 1994; Kasse et al., 2005, 2010; Kiss et al., 2015; Panin \& Matlakhova, 2015; Starkel et al., 2015). It was established that the major climate shift from the Pleniglacial to the Late-glacial was reflected, with variable delay, 
regionally in river systems by a change from braided to meandering. Several studies have identified multiple parallel functioning meandering channels during braided to meandering transitional stages at the Pleniglacial to Late-glacial and Younger Dryas to Holocene transitions (Vandenberghe et al., 1994; Erkens et al., 2011). However, short-lived climate events were recorded differently. For example, the response of river systems to the Younger Dryas cooling differed regionally and was not always reflected by meandering to braided channel planform changes, as in the Meuse and Rhine valleys. The Warta river in Poland (Vandenberghe et al., 1994), the Niers in Germany (Kasse et al., 2005) and the Tisza in Hungary (Kasse et al., 2010) persisted in a meandering mode during the Younger Dryas, and it was therefore concluded that the threshold towards braiding was not always crossed due to differences in gradient, stream power, lithology and bank stability. Even intra-catchment variable response to external forcing was established in the Wetter valley in Germany (Houben, 2003).

In addition to climate-related planform changes of river systems, climate change may also be reflected by short phases of fluvial instability, with incision and terrace formation. For this reason former floodplains and palaeochannels may be preserved and their geomorphology, lithology and palynology can be studied. At both cold-warm and warm-cold climate transitions changes in precipitation, evapotranspiration, river discharge and soil cohesion result in changes in the water/sediment ratio which can lead to incision and terrace formation (Vandenberghe, 1995, 2008). However, in most fluvial terrace staircase records the products of cold-warm and warmcold transitions are poorly preserved due to widespread lateral erosion and valley widening by braided systems in the next cold phase. In many cases, only the fluvial archive related to the last glacial-interglacial transition has been preserved, as is the case in the Roer valley, enabling reconstructions and dating of glacial-interglacial fluvial-systems changes. Although the main rivers Rhine and Meuse have received most attention in the Netherlands (Van den Broek \& Maarleveld, 1963; Berendsen et al., 1995; Kasse et al., 1995; Huisink, 1997; Tebbens et al., 1999; Van Huissteden \& Kasse, 2001; Cohen, 2003; Busschers et al., 2007; Hijma et al., 2009; Erkens et al., 2011), their tributaries have been studied in some detail as well. From the reconstructed fluvial development of the Geul (De Moor et al., 2008), Niers (Kasse et al., 2005), Lippe and Oude IJssel (Janssens et al., 2012) it was concluded that river system changes in the tributaries differ in some aspects from those seen in the main rivers. In this study we focus on the Roer river, a tributary of the Meuse. Despite its moderate catchment size, it has so far received little attention (Van den Broek \& Van der Marel, 1964; Schalich, 1968; Van Zuidam, 1980; Van den Berg, 1989; Bakels, 2017). The age control on the Late-glacial and Holocene development is still poor (Hoek, 1997b: sites RM03, RM04, Melick). Attempts have been made to fill this knowl-

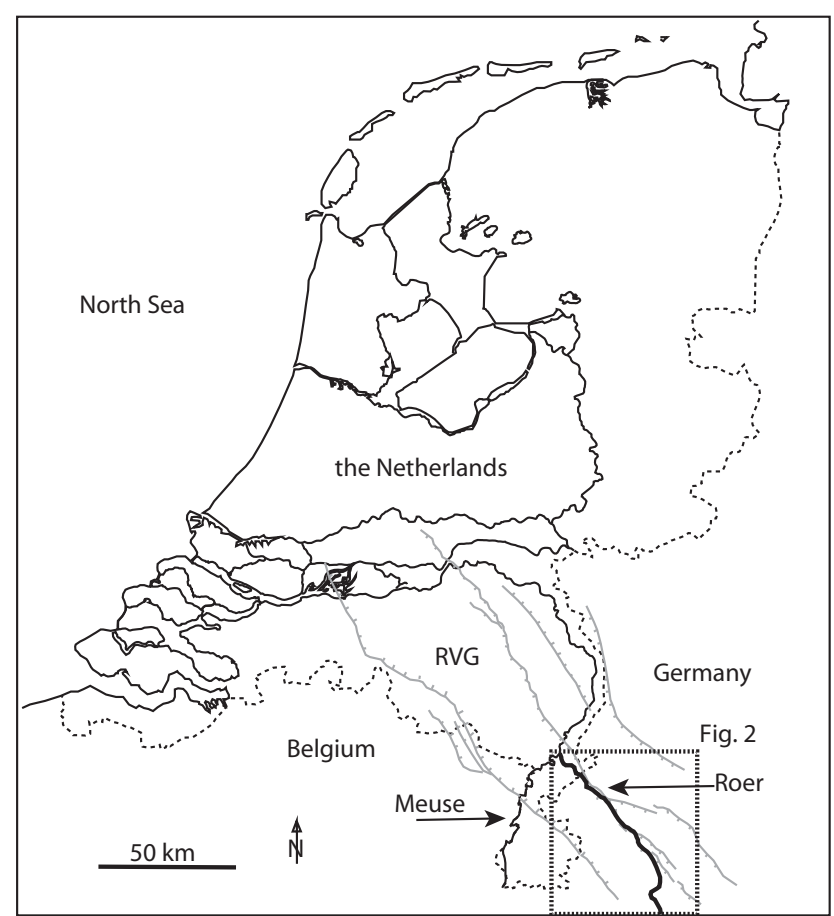

Fig. 1. Location map and tectonic setting of the study area in the southeastern Netherlands and western Germany. RVG = Roer Valley Graben.

edge gap in several bachelor and master research projects (Van Bostelen \& Vreugdenhil, 2009; Janssens, 2011; Vreugdenhil, 2011).

The aims of this study are to: (1) reconstruct the Late Pleniglacial, Late-glacial and Early Holocene fluvial channel pattern changes, incision events and terrace formation in the lower Roer valley; (2) establish the impact of climate change on the vegetation and the fluvial system; and (3) explore the role of the Meuse as a local base level for the Roer.

\section{Study site}

The Roer (Rur in Germany) catchment $\left(2354 \mathrm{~km}^{2}\right)$ is situated in the southern Netherlands and adjacent parts of Germany and Belgium (Figs 1 and 2). The Roer has a length of $165 \mathrm{~km}$ and its source in the Hautes Fagnes in Belgium is at an altitude of $660 \mathrm{~m}$ a.s.l. The river debouches into the Meuse near Roermond at an altitude of c. $19 \mathrm{~m}$ a.s.l. The mean annual discharge (AD 1969-2009) at Stahe, c. $7 \mathrm{~km}$ upstream of the Dutch-German border in Germany, is $21.8 \mathrm{~m}^{3} \mathrm{~s}^{-1}$ and the discharge varies between 8 and $124 \mathrm{~m}^{3} \mathrm{~s}^{-1}$. The Roer river is located in the SENW-oriented Roer Valley Graben bounded by the Peel Boundary Fault zone in the northeast and the Feldbiss Fault zone in the southwest (Fig. 1). The current extension phase of the graben started at the Oligocene-Miocene transition (Van Balen et al., $2000,2005)$. The graben was filled with Rhine and Meuse river deposits during the Early and Middle Pleistocene until $\sim 400 \mathrm{ka}$, and with local fluvial and aeolian sediments after that time 


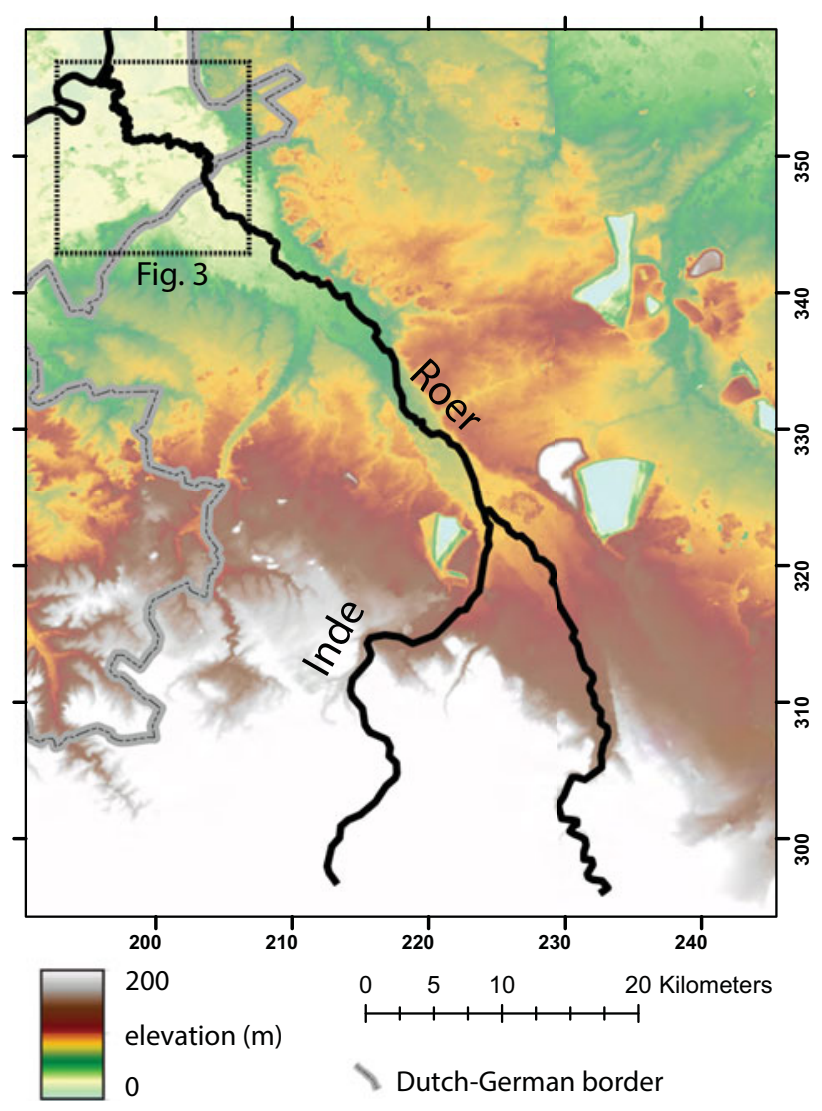

Fig. 2. Digital elevation map of the Roer river catchment. Coordinates according to the Dutch Ordnance System. For location see Figure 1.

(Schokker et al., 2005). The Roer Valley Graben is tectonically active, as demonstrated by c. $1 \mathrm{~m}$ displacement of Allerød-age terraces and Younger Dryas dunes along the Peel Boundary Fault (Michon \& Van Balen, 2005). Despite long-term subsidence of the Roer Valley Graben relative to adjacent areas, well-developed terraces and palaeochannels have formed in the confluence area of the Roer and Meuse during the glacial-interglacial transition, related to climate change.

\section{Methods}

The geomorphological analysis was based on topographical maps $(1: 25,000)$, digital elevation models of the Netherlands (AHN) and Germany and morphological mapping (Figs 3, 4 and 5). Morphogenetic units were distinguished based on surface morphology and elevation, location of terrace scarps, palaeochannel planform characteristics and cross-cutting relationships (Fig. 3b).

\section{Coring transects and lithological description}

Two main cross sections were cored perpendicular to the valley axis to investigate the lithology and to reconstruct the fluvial architecture of the area (Fig. 6). Five detailed lithological cross sections were made across abandoned channels to find the deepest and oldest infill for pollen analysis, to investigate vegetation development and to date the timing of channel abandonment (Figs 5 and 7). Coring was performed with an Edelman auger, a gauge and Van der Staay suction-corer. Sediment description in the field was done according to the Dutch classification of unconsolidated soil samples (NEN-5104). In this paper, textural classes according to the United States Department of Agriculture (USDA) have been used. Sampling for pollen analyses from the fills of abandoned channels was done with a gauge or piston corer (diameter $6 \mathrm{~cm}$ ).

\section{Pollen analyses}

Pollen analysis was performed to reconstruct the vegetation development (Figs 8, 9, 10 and 11). Local pollen assemblage zones, based on changes in species composition, were correlated to the existing biochronostratigraphic zonation for the Late-glacial and the Early Holocene in the Netherlands (Hoek, 1997a). This provides an indirect dating tool for fluvial system change. The cores from the palaeochannels were described in detail in the laboratory. A total of 48 samples from four cores were selected, based on lithology and lithological transitions. The pollen samples were prepared according to standard procedures (Faegri \& Iversen, 1989). The pollen slides were examined using a Zeiss Axioskop 50 light microscope with a magnification of $630 \times$ with and without phase contrast. Pollen determination was conducted using the pollen key of Moore et al. (1991). The pollen sum varied between 100 and 200 and included tree taxa, shrubs and upland herbs. Wetland herbs, aquatics and Cyperaceae were excluded from the pollen sum. Pollen diagrams were constructed using TILIA software in which taxa are arranged in ecological groups (Grimm, 1992).

\section{Optically stimulated luminescence dating}

Fluvial and aeolian sands were sampled for luminescence dating to reconstruct meandering channel dynamics, and to date incision events and aeolian dune formation (Fig. 4; Table 1). Boreholes were made with an Edelman corer (10 cm diameter), and the disturbed and bioturbated soil and fine-grained overbank sediments were removed down to the sampling depth. Sampling was done in the boreholes by vertically hammering $40 \mathrm{~cm}$ long stainless steel tubes with a diameter of $7 \mathrm{~cm}$ into the sand (Van der Horst coring equipment). The optically stimulated luminescence (OSL) samples were taken from homogeneous sand units, mostly with a median grain size of $210-300 \mu \mathrm{m}$, to exclude the effect of lithological variability. A total of 11 OSL samples were collected. Eight samples were collected from fluvial pointbar deposits at 1-2 $\mathrm{m}$ depth below the surface, to prevent the influence of later overbank deposition, soil formation and bioturbation. Sample Kraamweg 8 was taken from the sandy infill of a meander 
(A)

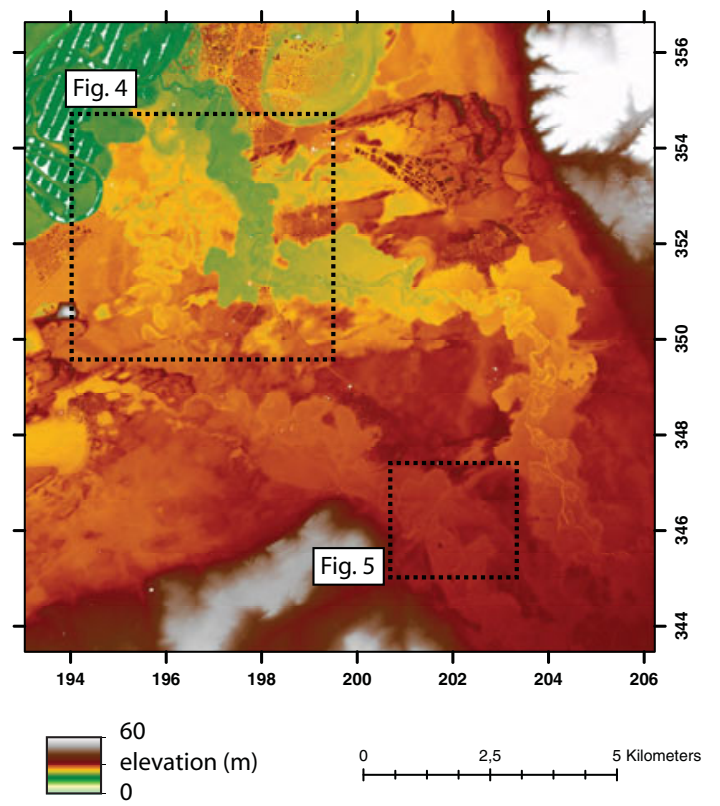

(B)
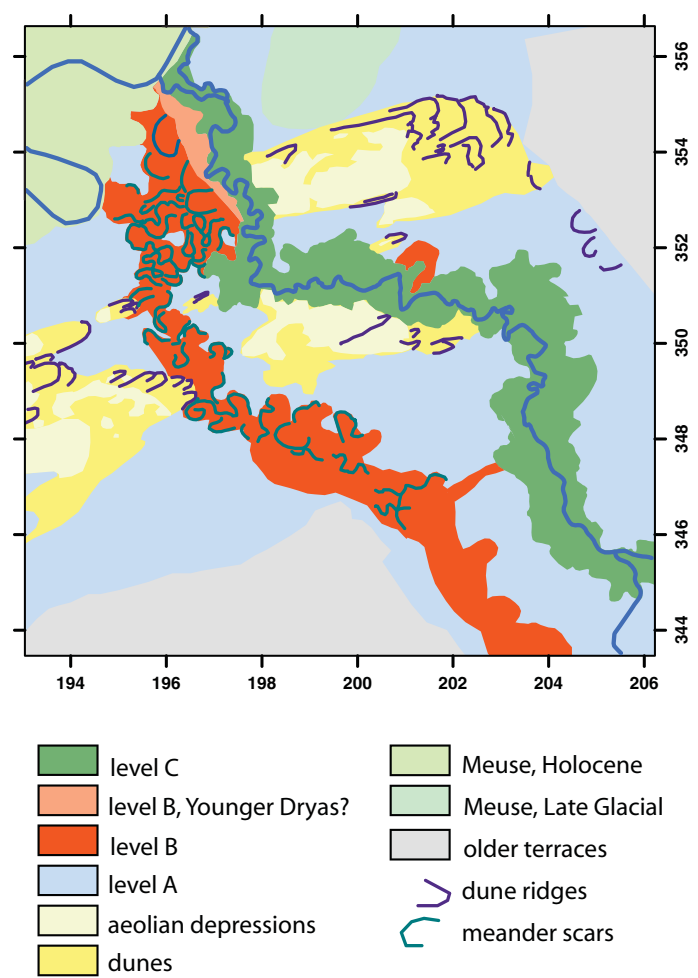

(C)

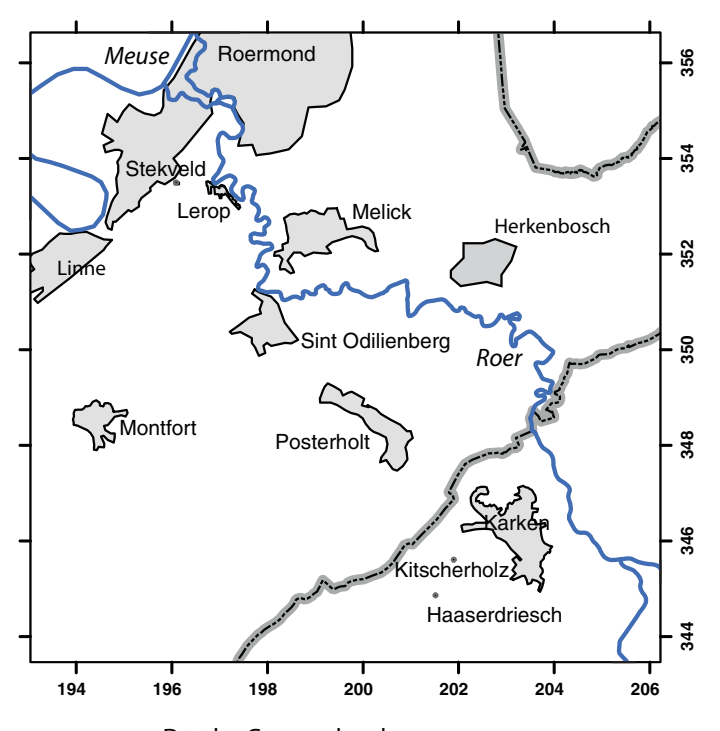

Dutch - German border

Fig. 3. (A) Digital elevation map of the lower reaches of the Roer; (B) morphogenetic interpretation of the study area with the terraces and floodplain levels, aeolian deflation and accumulation areas; (C) locations mentioned in the text. For location see Figure 2. 


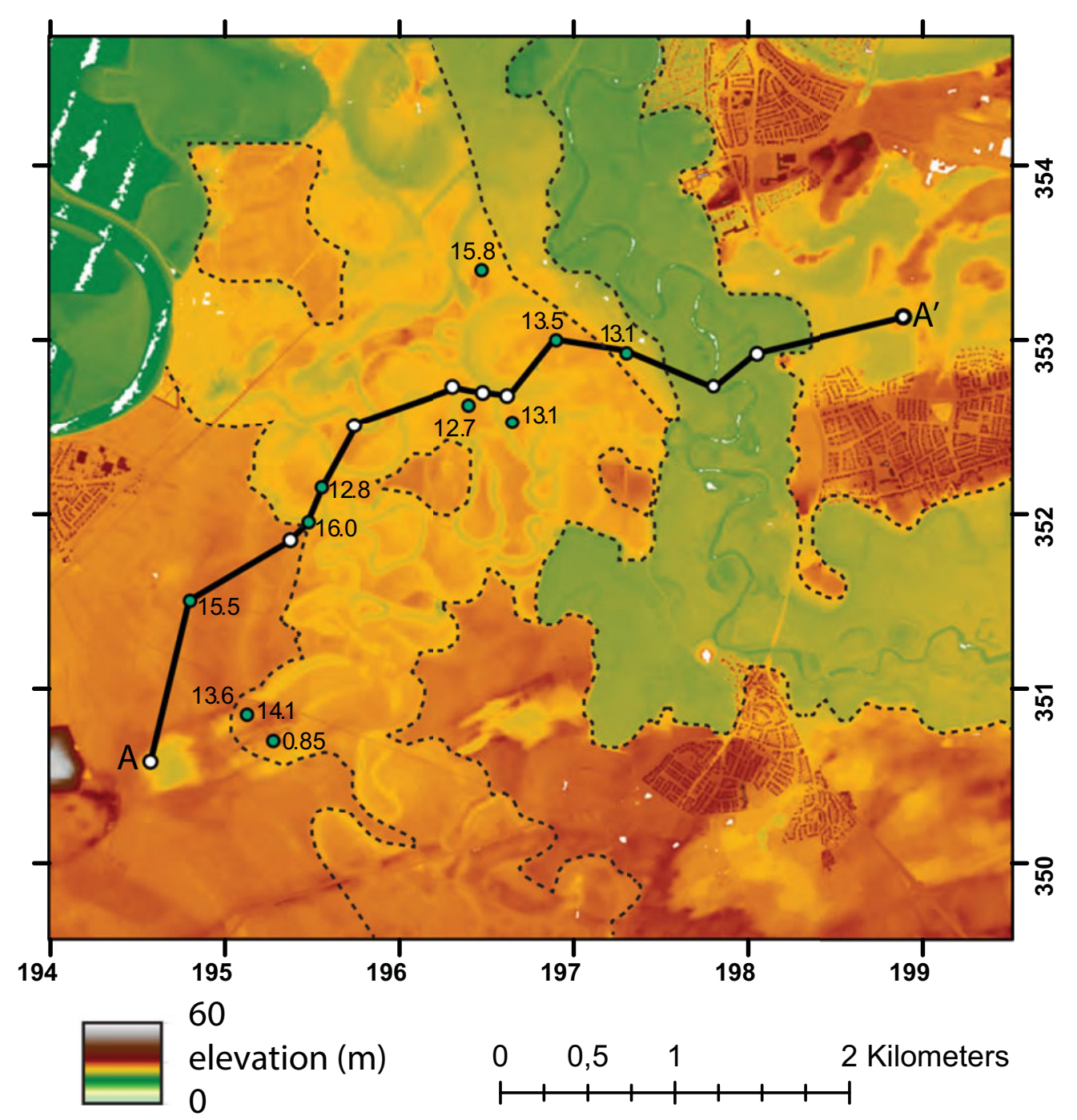

Fig. 4. Digital elevation map of Late-glacial level B and Holocene floodplain level $C$ in the downstream part of the Roer valley. Position of cross section AA', corings (open dots) and OSL-sample locations (closed dots) and ages in ka are indicated. For location see Figure 3.

channel. Samples Bergerweg 14 and 16 were taken at a shallower depth from aeolian dune deposits overlying meandering level B.

In the laboratory of the Netherlands Centre for Luminescence Dating (situated at Delft University of Technology at the time of analysis) samples were split into two parts. Outer ends of the sample tubes were exposed to light during sampling, and were used to determine the dose rate. Activity concentrations of radionuclides were determined with gamma spectrometry, and dose rates were calculated taking into account attenuation due to water and grain size, and a contribution from cosmic rays (for details see Sevink et al., 2013 and references therein).

Material from the inside of the sample tubes was prepared for equivalent dose determination. Quartz grains of size 180-212 $\mu \mathrm{m}$ were prepared for analysis, and purity of quartz extracts was tested by measuring the luminescence response to infrared stimulation (Duller, 2003). Luminescence measurements were made using Risø TL/OSL-DA-15 and DA-20 instruments (Bøtter-Jensen et al., 2003), equipped with an internal $1.48 \mathrm{GBq}{ }^{90} \mathrm{Sr} /{ }^{90} \mathrm{Y}$ source for irradiation, and blue light-emitting diodes (LEDs) for optical stimulation $\left(470 \mathrm{~nm}, \sim 35 \mathrm{~mW} \mathrm{~cm}^{-2}\right.$ ). Quartz luminescence signals were collected by a selected photomultiplier tube, using $7.5 \mathrm{~mm}$ of U340 filters to block the stimulating light and select the quartz emission around $340 \mathrm{~nm}$. The single-aliquot regenerative (SAR) dose procedure (Murray \& Wintle, 2000, 2003) was applied for equivalent dose determination, using small aliquots ( $2 \mathrm{~mm} ; \sim 100$ grains) to minimise within-aliquot averaging and allow detection of heterogeneous bleaching (Cunningham et al., 2011).

Based on preheat plateau tests for a subset of the samples, a preheat of $240^{\circ} \mathrm{C}$ and cutheat of $220^{\circ} \mathrm{C}$ were selected. Stimulation was for $20 \mathrm{~s}$ at $125^{\circ} \mathrm{C}$; an early background approach was adopted to obtain net OSL signals (Cunningham \& Wallinga, 2010; initial signal 0-0.5 s; background 0.5-1.75 s), and at the end of each SAR cycle the signals were bleached by blue LEDs for $40 \mathrm{~s}$ at $260^{\circ} \mathrm{C}$. The adopted protocol was tested using a dose recovery test, yielding excellent results (average $0.99 \pm 0.02$; 


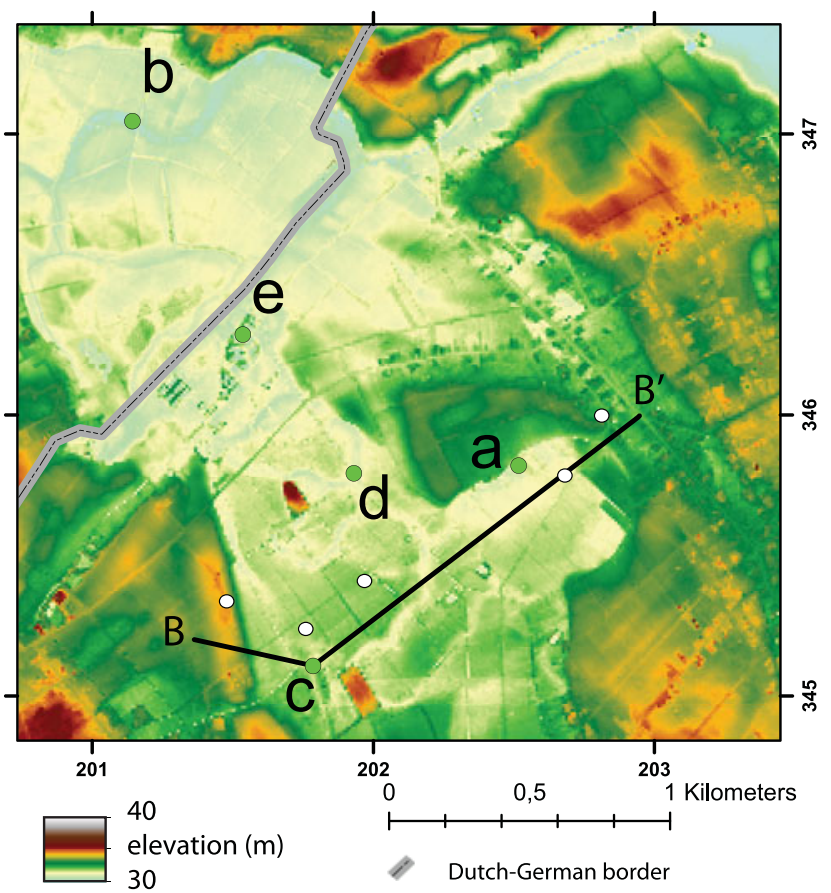

Fig. 5. Digital elevation map of Late-glacial level $B$ in the Roer valley at the Dutch-German border. Position of cross section $B B^{\prime}$, corings (open dots) and locations of pollen diagrams from abandoned channels (green dots) are indicated ( $a=$ Karken; $b=$ Geraerds; $c=$ Haaserdriesch; $d=$ Kitscherholz; $e=$ Kitscherholz b). For location see Figure 3.

$n=25$ ). Each measurement included a recycling test (threshold $10 \%$ from unity), recuperation test (threshold $10 \%$ of first regenerative response) and feldspar test (threshold infrared signal $<20 \%$ of blue signal, and infrared depletion $<10 \%$ ). Measurements were repeated for each sample until at least 22 aliquots passed rejection criteria; for one sample additional measurements were made $(n=40)$ to allow interpretation of the complex dose distributions. To obtain burial doses from the equivalent dose distributions, the Central Age Model (Galbraith et al., 1999) was used for all but one sample (see discussion below). Burial ages were obtained by dividing the equivalent dose by the dose rate, taking into account all uncertainties in both. Uncertainties reflect one sigma, and ages are reported in ka relative to the year of sampling (2008). For sample NCL-6108166 an overdispersed and skewed dose distribution indicated heterogeneous bleaching. For this sample, a bootstrapped version of the minimum age model (BSMAM) was used (Cunningham \& Wallinga, 2012). Based on the overdispersion of the other fluvial samples in this study, an overdispersion of $15 \pm 2 \%$ due to other sources than heterogeneous bleaching was used for the BSMAM analysis.

\section{Results}

Three (palaeo)floodplain levels, separated by terrace scarps, were distinguished in the lower reaches of the Roer valley
(Fig. 3), based on elevation, differences in surface morphology and lithological characteristics.

\section{Level A}

Morphology The elevation in the study area declines from $34 \mathrm{~m}$ a.s.l. near Karken to $28 \mathrm{~m}$ a.s.l. in the downstream area near Linne, resulting in a valley gradient of $c .55 \mathrm{~cm} \mathrm{~km}^{-1}$. Level A is characterised by gentle relief of $1.5 \mathrm{~m}$ and an undulating morphology; neither fluvial channel patterns nor pointbar features were observed at this level. Extensive aeolian dune fields with parabolic dune forms, up to $10 \mathrm{~m}$ high, are present at level $\mathrm{A}$. These dune fields are situated at the northeastern side of circular to oval-shaped deflation hollows (Fig. 3).

Lithology Few observations were done on this level. In the downstream area, fine to medium and locally gravelly coarse sands are overlain by 1-2 $\mathrm{m}$ loamy sand and sandy loam (Fig. 6: cross section $\mathrm{AA}^{\prime}$, unit A1) (after Van Bostelen \& Vreugdenhil, 2009). The upper $\sim 5 \mathrm{~m}$ mostly consist of slightly to moderately loamy, fine to medium sand $(150-420 \mu \mathrm{m})$ with weakly developed fining-upward sequences of $<2 \mathrm{~m}$ thickness (unit A2). In the more upstream part of the study area medium to coarse gravelly sand is overlain by 2-3 $\mathrm{m}$ of loamy, fine to medium sand (Fig. 6: cross section $\mathrm{BB}^{\prime}$, units $\mathrm{A} 1$ and $\mathrm{A} 2$ ) (after Vreugdenhil, 2011).

Chronology One sample was taken from level A for OSL dating (NCL-6108159; Stella Maris 3) (Fig. 4; Table 1). The age of $15.5 \pm 1.1 \mathrm{ka}$ indicates a Late Pleniglacial age close to the Lateglacial boundary of $14.7 \mathrm{ka}$. The equivalent dose distribution for this sample was broader than for other samples, with an overdispersion of $23 \%$. This may indicate mixing of grains of different age, or heterogeneous bleaching of the sample. However, there were no clear signs of poor-bleaching (e.g. skewed distribution), and hence the Central Age Model (CAM) was adopted for determining the burial dose.

\section{Level B}

Morphology Level B is situated south of the present-day Roer meander belt as a palaeosystem that is incised in level A (Fig. 3). It dips from $32 \mathrm{~m}$ a.s.l. at the Dutch-German border near Karken to $25 \mathrm{~m}$ a.s.l. near the confluence with the Meuse (valley gradient of $c .62 \mathrm{~cm} \mathrm{~km}^{-1}$ ). The channel-belt width increases from $c$. $1 \mathrm{~km}$ in the southeast to $2 \mathrm{~km}$ in the northwest. Level B is characterised by well-developed high-sinuosity palaeomeanders of several generations, locally with neck-cut-off morphology, testifying to intense lateral channel migration. The present relief difference between palaeochannels and pointbar surfaces increases from $c .1 \mathrm{~m}$ in the more upstream part of the study area to $c$. $2 \mathrm{~m}$ in the downstream part. In the downstream part of level $\mathrm{B}$, palaeomeanders with a larger amplitude and width are present at a lower elevation of c. $25 \mathrm{~m}$ a.s.l. (Figs $3 \mathrm{a}$ and 4). These larger 


\section{Transect A - A'}

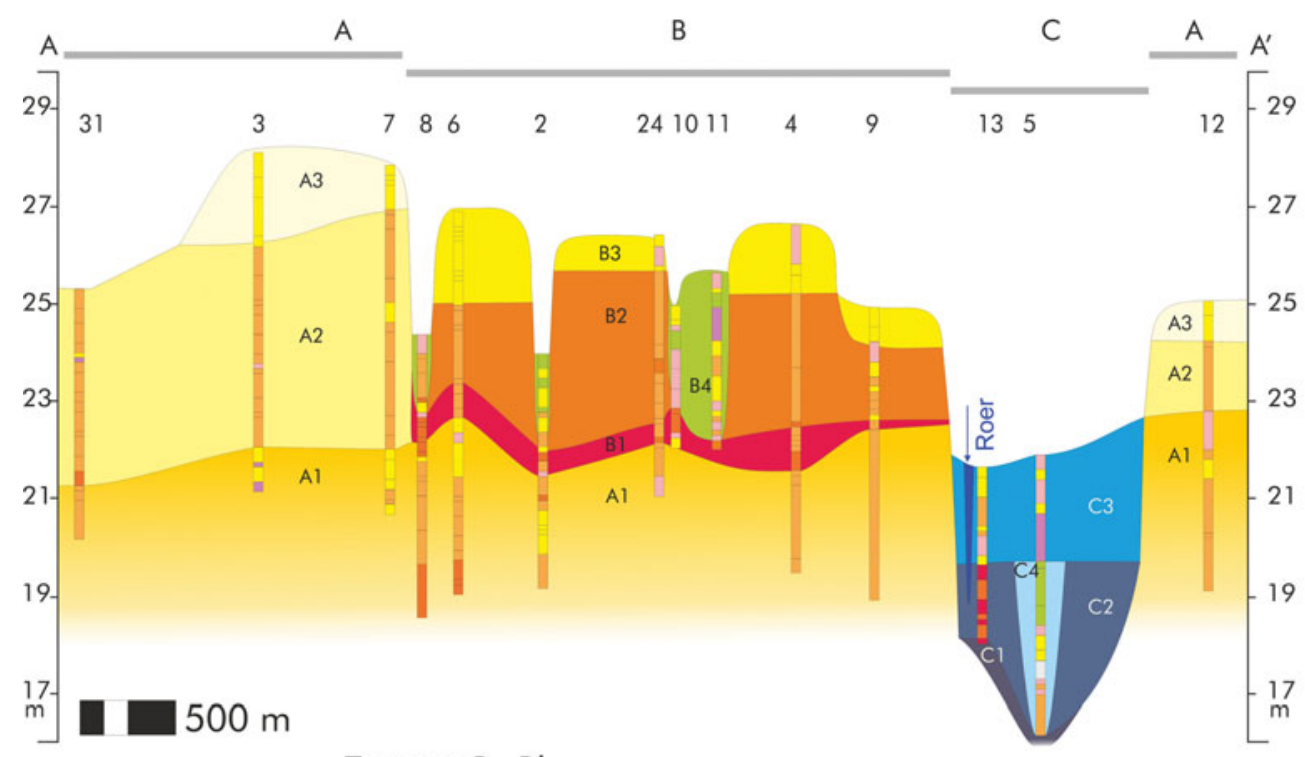

Transect B - B'

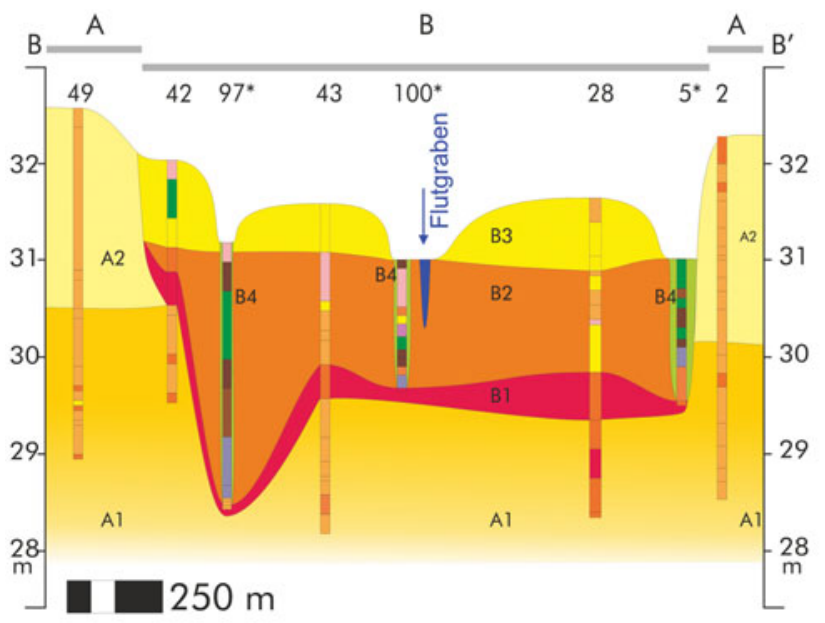

Lithology in cores

Gyttia

Peat

Clayey peat

Humic Clay

Silty clayloam to clay
Sandy clayloam to sandy clay

Loam

andy loam

oamy sand to sandy loam

ine to medium sand (M50: 105-420 $\mu \mathrm{m}$

Coarse to gravelly sand (M50: $420-2000 \mu \mathrm{m}$ )

Sandy gravel to gravel (M50: > $2000 \mu \mathrm{m})$

Lithogenetic Units

C4 Channel fill deposits

C3 Overbank deposits

C2 Channel and pointbar deposits

C1 Lag deposits

B4 Channel fill deposits

B3 Overbank deposits

2 Channel and pointbar deposits

B1 Lag deposits

A3 Aeolian deposits

A2 Fluvio-aeolian deposits

A1 Fluvial deposits

Fig. 6. Lithogenetic cross section $A A^{\prime}$ and schematic cross section $B B^{\prime}$ with projected core data over the Roer valley showing the fluvial architecture of levels $A, B$ and $C$. For location see Figures 4 and 5 .

meanders are dissected by a southeast-northwest-oriented small terrace scarp near Lerop, resulting in a local intermediate level between level B and the Holocene floodplain C (Fig. 3). Locally, northeast and north of Montfort, level B is covered by parabolic dune forms (Figs 3 and 4).

Lithology The channel lag and pointbar deposits in the downstream part, at cross section $\mathrm{AA}^{\prime}$, are up to $5 \mathrm{~m}$ (smaller meanders) or $6 \mathrm{~m}$ (larger meanders) thick, with a lower boundary at c. $22 \mathrm{~m}$ a.s.l. (Van Bostelen \& Vreugdenhil, 2009) (Fig. 6: cross section $\left.\mathrm{AA}^{\prime}\right)$. The lithological successions are characterised by a channel lag deposit of slightly gravelly, medium to coarse sand $(300-850 \mu \mathrm{m})$ (unit B1), overlain by pointbar sediments with fining-upward sequences of coarse to medium sand (300-600 $\mu \mathrm{m})$ grading to fine sand (150-300 $\mu \mathrm{m}$ ) (unit
B2). The upper part consists of loamy sand (105-210 $\mu \mathrm{m})$ and sandy loam (unit B3). The lithology and surface morphology indicate that the upper part was formed by overbank deposition of suspended material on the pointbars. The channel lag and pointbar deposits in the more upstream area are $c .3 \mathrm{~m}$ thick with a lower boundary at $29 \mathrm{~m}$ a.s.l. (Vreugdenhil, 2011) (Fig. 6: cross section $\mathrm{BB}^{\prime}$ ). The lithological trends are similar, but the sedimentary sequences are thinner and gravel content of the channel lag deposits is higher than in the downstream area.

The residual channel-fill deposits in the downstream area are generally 2-3 $\mathrm{m}$ thick in the smaller abandoned meanders and up to $4 \mathrm{~m}$ in the large meanders and are dominated by clastic deposits of the Roer (Fig. 6: cross section $\mathrm{AA}^{\prime}$, unit B4) (Van Bostelen \& Vreugdenhil, 2009). Most channel fills show 


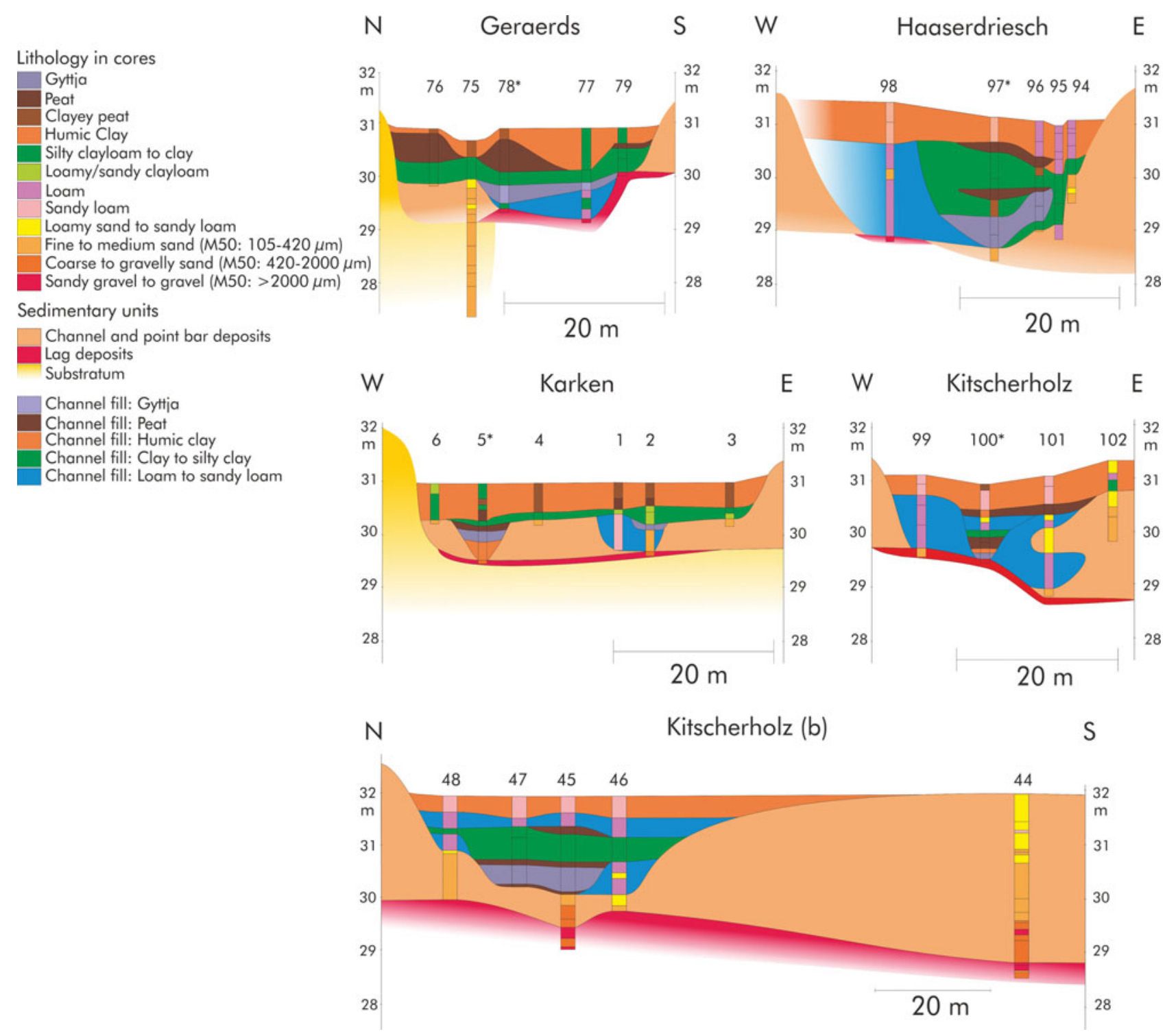

Fig. 7. Lithogenetic cross sections over abandoned channels of level B in the Dutch-German border area of the Roer valley. Asterisks indicate positions of pollen diagrams. For location see Figure 5.

a fining-upward sequence with medium to coarse sand (300$600 \mu \mathrm{m})$ grading to fine sand $(150-300 \mu \mathrm{m})$ and loamy fine sand $(150-210 \mu \mathrm{m})$. Locally the upper part of the fill consists of clay, loam and loamy sand. The residual channel fills in the upstream part of the study area are generally $1.5-2.5 \mathrm{~m}$ thick and contain an alternation of organic (gyttja and peat) and clastic units (loam and clay) deposited by the Roer and tributary brooks (Fig. 6: cross section BB', unit B4) (Vreugdenhil, 2011).

Palynology Because of the presence of fine-grained and organic units in the abandoned meanders in the upstream part of level B, five detailed cross sections were made over the palaeochannels (Figs 5 and 7). The deepest locations were sampled for pollen analysis. The general outline of the vegetation development is described below. A detailed description of the lithology, local pollen zones and biostratigraphical interpretation is provided in the Appendix. The local pollen zones are correlated with the radiocarbon-dated biostratigraphy of Hoek (1997a,b).

Sites Karken, Geraerds and Haaserdriesch (Figs 8-10) demonstrate that the first infill of the abandoned channels is characterised by low arboreal pollen and high values in Poaceae and heliophilous herbs that can be correlated with the Older Dryas (PAZ 1c) biozone. The Kitscherholz palaeochannel (Fig. 11) shows a younger infill that started in the later part of the Younger Dryas biozone.

The vegetation shows an increase in trees, especially of Betula during the Allerød (PAZ 2a) (Figs 8-10). The increase of Pinus, characteristic for the second part of the Allerød (PAZ 2b), was 


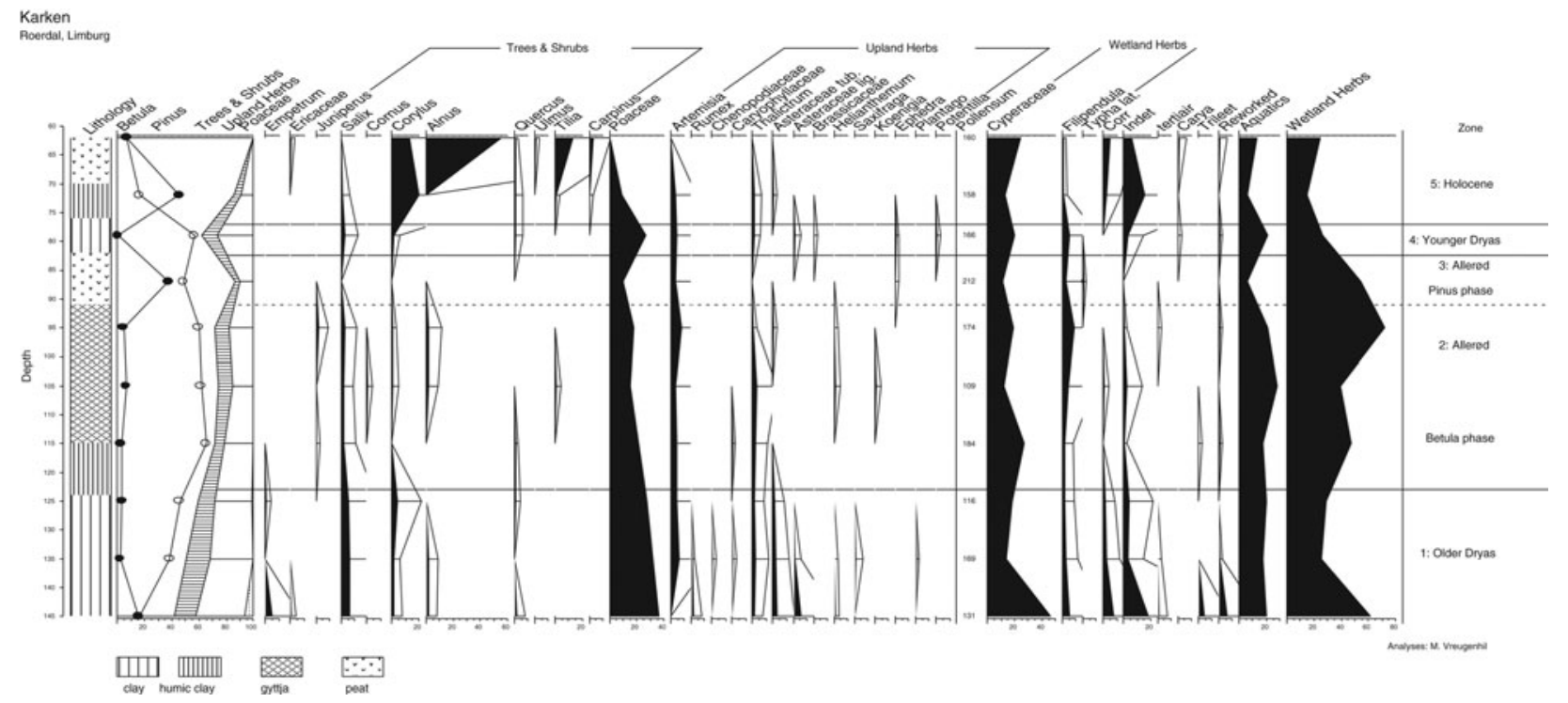

Fig. 8. Pollen diagram Karken. For location see Figure 5.

only observed at site Karken (Fig. 8). Shielding effects by Salix stands near the Haaserdriesch palaeochannel may have reduced the influx of Pinus pollen (Fig. 10).

The Younger Dryas biozone (PAZ 3) is reflected by an increase in grasses and heliophilous herbs in the diagrams, indicating more open vegetation and unstable soil conditions (Figs 8-10). The lithology of the channel fills at the three sites changes from organic to clay deposits at the Allerød to Younger Dryas transition.

The pollen diagrams show a rapid increase in arboreal pollen marking the onset of the Early Holocene (Figs 8-11). Diagrams Geraerds and Karken reveal a hiatus, associated with soil formation, covering the Preboreal biozone (Figs 8 and 9). In the deeper palaeochannel Haaserdriesch, the Early Holocene record is complete. Juniperus and Betula show a peak during the Preboreal (Figs 10 and 11), followed by an increase in Pinus and Corylus during the Boreal (Figs 8 and 9) and Alnus and Tilia during the Atlanticum (Fig. 8: diagram Karken).

In contrast to the upstream area, the meander-fill sediments in the downstream part of level B are exclusively clastic with a fining-upward sequence of sand, sandy loam and loam. The absence of organic material in the abandoned meanders is caused by groundwater levels below the base of the palaeochannels. The deep groundwater level is related to the incision of the Late-glacial and Early Holocene Meuse and downstream part of the Roer, therefore inhibiting the formation of oxbow lakes and organic accumulation. Instead, brown soils (Dutch ooivaaggronden, vorstvaaggronden) developed in the palaeochannels during the Holocene (Bodemkaart van Nederland, 1972).

Chronology In order to date the fluvial activity and abandonment of meandering level B, eight 0SL samples (NCL-6108158 and -160 to -166$)$, mostly from sandy pointbar deposits, and two samples from overlying dune sediments were dated (Table 1). It was hypothesised during sampling that spatial age differentiation could be present between the different meander generations of level B with younger meander sediments in the direction of the present-day floodplain (Fig. 4). However, the ages range from $16.0 \pm 1.1$ to $12.7 \pm 0.7 \mathrm{ka}$, and many dates overlap within errors. No systematic age trend can be observed in the morphological development.

Two samples from aeolian sediments from a parabolic dune complex overlying level B (Fig. 4) (NCL-6108157-156; Bergerweg 16 and 14) were dated at $13.6 \pm 0.9$ and $0.85 \pm 0.05 \mathrm{ka} /$ $\mathrm{AD} 1158 \pm 49$. The dates provide a minimum age for level $\mathrm{B}$. The date of Bergerweg $16(0.8 \mathrm{~m})$ is stratigraphically consistent with the date of $14.1 \pm 0.8 \mathrm{ka}$ from the underlying fluvial pointbar (NCL-6108158; Bergerweg 16: $2.4 \mathrm{~m}$ ). The aeolian deposits and parabolic dunes can be assigned to the Late-glacial, and the OSL age agrees within errors with the Younger Dryas stadial (12.9-11.7 ka) (Kasse, 1995b). The date of Bergerweg 14 $(0.85 \pm 0.05 \mathrm{ka} / \mathrm{AD} 1158 \pm 49)$ indicates a Medieval age and is surprisingly recent as it was expected to be from the same lithological unit as Bergerweg 16. Apparently, the sand has been locally reworked by aeolian processes and redeposited as drift sand.

\section{Level C (Holocene floodplain)}

Morphology The present-day Roer floodplain is situated at $c$. $28 \mathrm{~m}$ a.s.l. at the Dutch-German border and $19 \mathrm{~m}$ a.s.l. at the confluence with the Meuse and has a floodplain gradient of $c$. $75 \mathrm{~cm} \mathrm{~km}^{-1}$ (Fig. 3). This gradient is steeper than the valley gradient of meandering level $\mathrm{B}$, and both gradient lines converge upstream c. $10 \mathrm{~km}$ southeast of the Dutch-German border. The Roer is an unconstrained meandering river and the floodplain is 

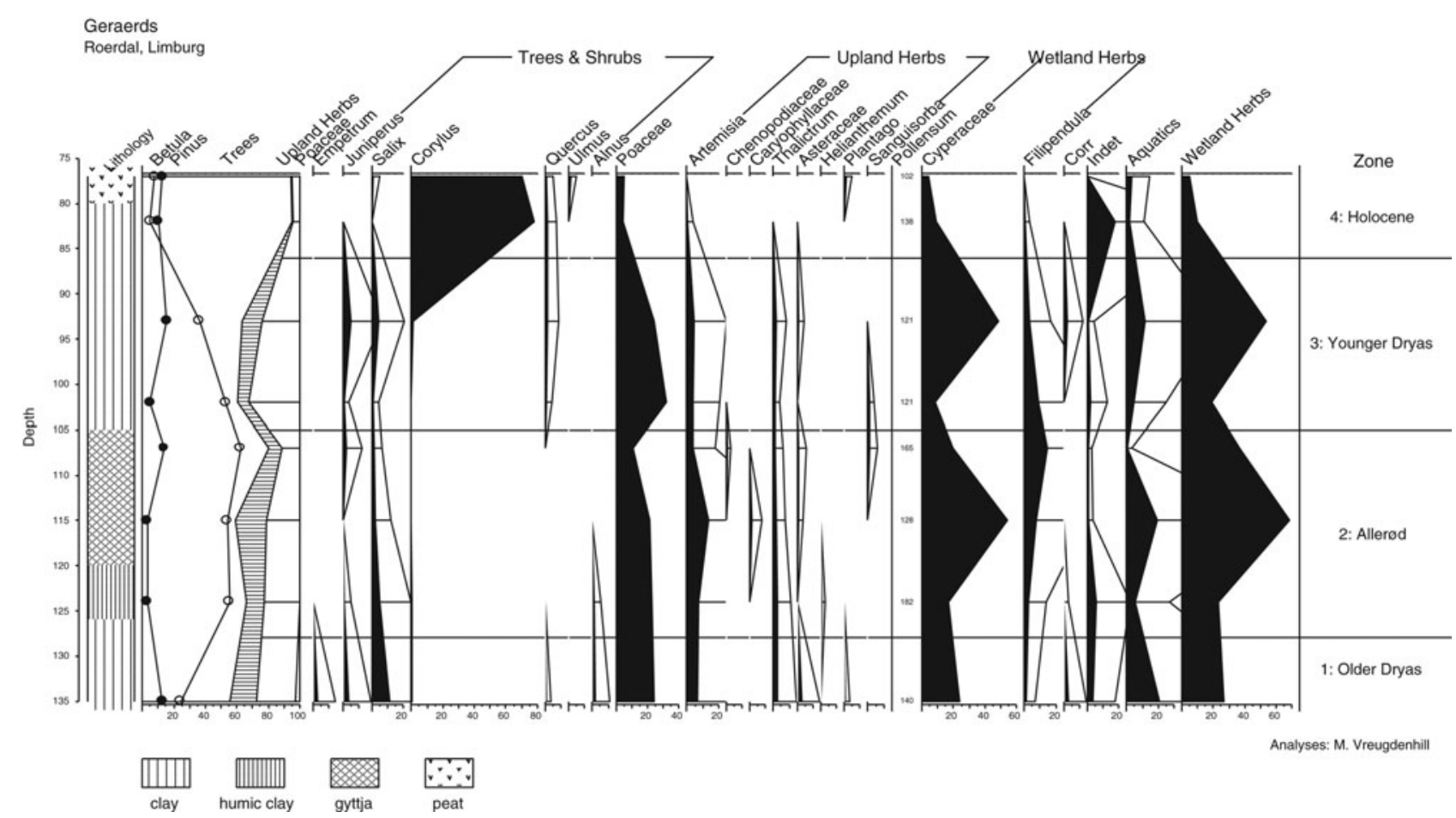

Analyses: M. Vreugdenhill

Fig. 9. Pollen diagram Geraerds. For location see Figure 5.

characterised by many meander scars, visible in the terrace scarp of c. 4-5 $\mathrm{m}$ between levels $B$ and $C$ in the downstream reach, and as remnants of oxbow lakes especially in the younger parts of the floodplain along the present-day river (Fig. 3a). Within the Holocene floodplain, two sublevels can be distinguished, especially downstream of the Dutch-German border (Janssens, 2011). In the downstream part of the floodplain, near the confluence with the Meuse, these two sublevels merge and only one floodplain can be distinguished. The morphological details and fluvial development of the Holocene floodplain level $\mathrm{C}$ are outside the scope of this paper, and only the main elements that constrain the Late-glacial to Early Holocene evolution are presented here.

Lithology The lithology of the Holocene floodplain is characterised mostly by fining-upward sequences (Janssens, 2011, fig. 8). Near Karken the floodplain sequence is $3 \mathrm{~m}$ thick, near Herkenbosch $4 \mathrm{~m}$ and downstream near Melick the sequence is $5 \mathrm{~m}$ thick (after Van Bostelen \& Vreugdenhil, 2009; Janssens, 2011) (Fig. 6: cross section $\mathrm{AA}^{\prime}$ ). At the base, channel lag deposits of gravel and coarse sand are overlain by medium to coarse-grained pointbar sands $(300-850 \mu \mathrm{m})$ and loamy sand and sandy loam overbank deposits (c. $2 \mathrm{~m}$ ) (units C1, C2, C3). The channel lag deposits of level $C$ are coarser-grained and have a higher gravel content than those of level B, where gravel is scarce. In addition, loam and clay layers that are restricted at level B to channel fills are more extensive at level C. Channel fills at level $C$ are up to $5 \mathrm{~m}$ thick in the downstream part near Melick (Fig. 6: cross section AA, unit C4). They consist of loamy fine sand at the base, grading upward into silty clay, clay loam and sandy loam deposited by the Roer. In general, the sediments at level $B$ are dominated by pointbar sands, while level $C$ is characterised by pointbar sands and floodplain loams.

\section{Interpretation and discussion}

The Late-glacial and Holocene fluvial development of the Roer is characterised by channel pattern changes, incision, and by terrace formation and abandonment of a channel belt.

\section{Late Pleniglacial evolution (level A)}

The undulating, irregular morphology and absence of fluvial morphology at the surface of level $\mathrm{A}$, in combination with loamy fine sand in the upper 1-2 $\mathrm{m}$ of the sedimentary succession, indicates that level A may be covered by aeolian coversand deposits with limited relief (Fig. 3a). At the base of the succession thin fining-upward sequences, gravel and coarse sand have been observed pointing to fluvial channel deposition. The intermediate zone, characterised by an alternation of medium sand and loamy beds, may be interpreted as fluvial bar and overbank sediments (Fig. 6: cross section $\mathrm{AA}^{\prime}$, top unit A1). The absence of fluvial surface morphology hampers the genetic interpretation in terms of meandering or braided, as all fluvial systems are characterised by fining-upward sequences (Bridge, 1985). However, the absence of long fining-upward sequences, as has been found at level B, and the apparent absence of large channel fills, 


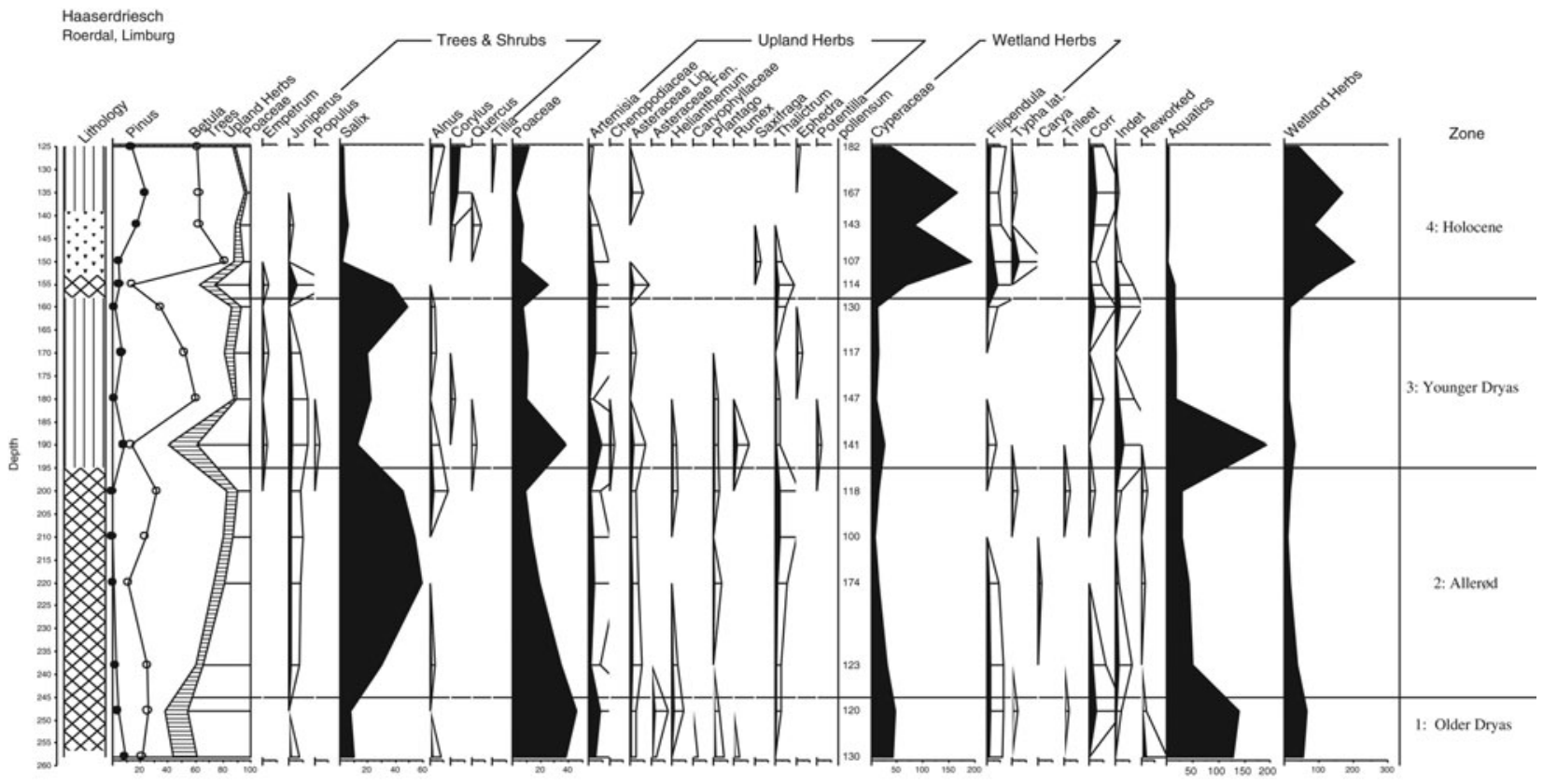

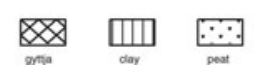

Fig. 10. Pollen diagram Haaserdriesch. For location see Figure 5.

\section{Kitscherholz}

Roerdal, Limburg

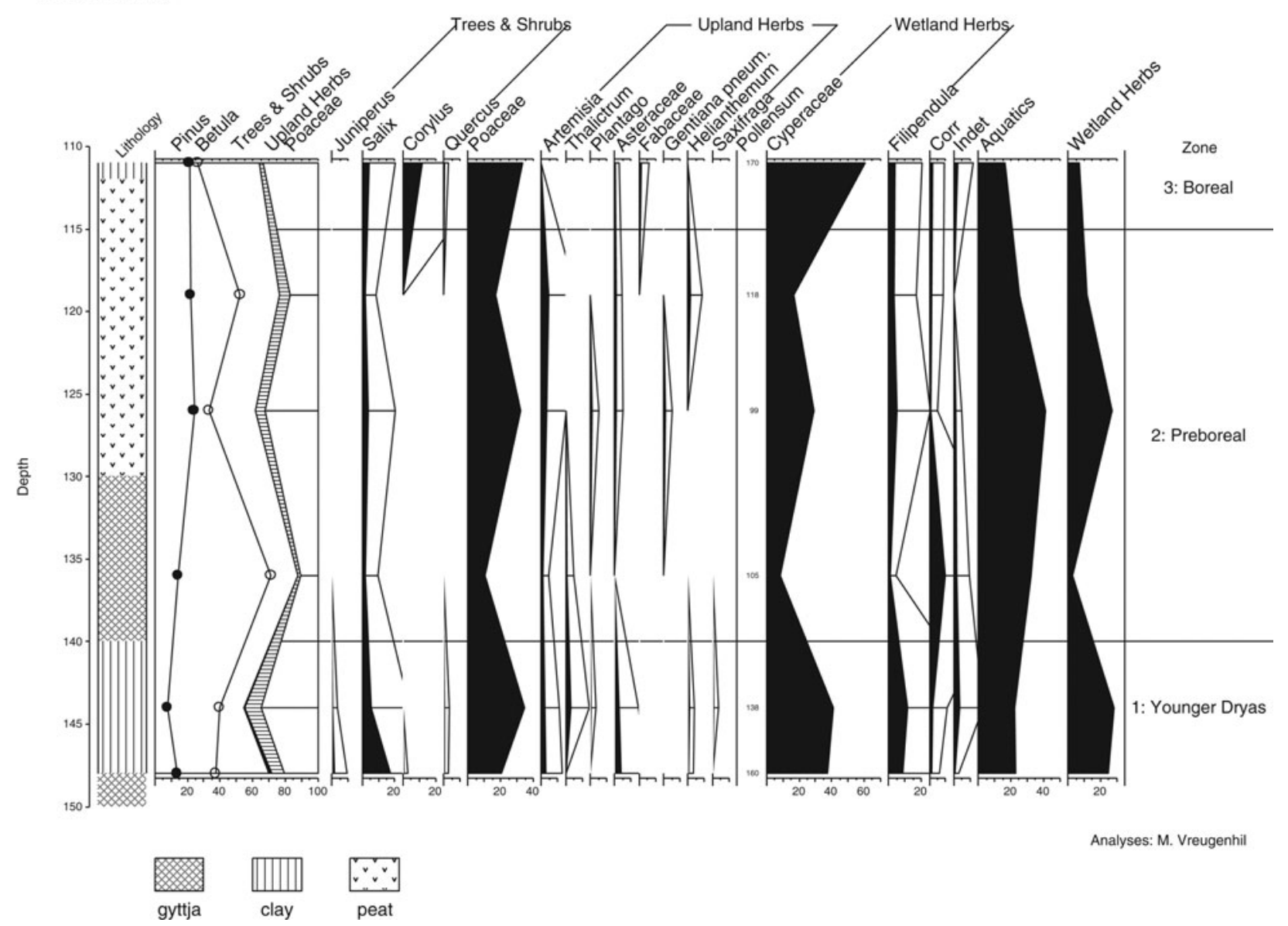

Fig. 11. Pollen diagram Kitscherholz. For location see Figure 5. 
Table 1. Quartz optical dating results of pointbar, channel and aeolian sediments from level B. For location of the samples see Figure 4.

\begin{tabular}{|c|c|c|c|c|c|c|c|c|c|}
\hline \multicolumn{2}{|r|}{ Sample } & \multicolumn{3}{|c|}{ Location } & \multirow{2}{*}{$\begin{array}{l}\text { Equivalent } \\
\text { dose (Gy) }\end{array}$} & \multirow{2}{*}{$\begin{array}{l}\text { Dose rate } \\
\left(\mathrm{Gy} \mathrm{ka}^{-1}\right)\end{array}$} & \multirow[b]{2}{*}{ Age (ka) } & \multirow[b]{2}{*}{ Validity } & \multirow{2}{*}{$\begin{array}{l}\text { Age } \\
\text { model }\end{array}$} \\
\hline NCL & Client & $\bar{x}$ & $\mathbf{Y}$ & Depth (m) & & & & & \\
\hline 6108156 & Bergerweg 14 & 195275 & 350700 & 0.9 & $0.70 \pm 0.03$ & $0.83 \pm 0.03$ & $0.85 \pm 0.05$ & OK & CAM \\
\hline 6108157 & Bergerweg 16 & 195125 & 350850 & 0.8 & $13.92 \pm 0.43$ & $1.02 \pm 0.06$ & $13.6 \pm 0.9$ & OK & CAM \\
\hline 6108158 & Bergerweg 16 & 195125 & 350850 & 2.4 & $18.60 \pm 0.70$ & $1.32 \pm 0.05$ & $14.1 \pm 0.8$ & Likely OK & CAM \\
\hline 6108159 & Stella Maris 3 & 194800 & 351500 & 1.5 & $16.11 \pm 0.88$ & $1.04 \pm 0.05$ & $15.5 \pm 1.1$ & Likely OK & CAM \\
\hline 6108160 & Kraamweg 8 & 195475 & 351950 & 1.4 & $16.68 \pm 0.85$ & $1.04 \pm 0.05$ & $16.0 \pm 1.1$ & Likely OK & CAM \\
\hline 6108161 & Linnerheide 6 & 195550 & 352150 & 1.45 & $12.31 \pm 0.74$ & $0.96 \pm 0.04$ & $12.8 \pm 0.9$ & Questionable & CAM \\
\hline 6108162 & Gulikerweg 1 & 196400 & 352625 & 1.5 & $13.58 \pm 0.54$ & $1.07 \pm 0.04$ & $12.7 \pm 0.7$ & Questionable & CAM \\
\hline 6108163 & Stekveldweg 29 & 196475 & 353400 & 2.2 & $21.89 \pm 0.66$ & $1.38 \pm 0.06$ & $15.8 \pm 0.9$ & OK & CAM \\
\hline 6108164 & Lerop 9 & 197300 & 352925 & 1.9 & $16.42 \pm 0.62$ & $1.25 \pm 0.04$ & $13.1 \pm 0.7$ & Likely OK & CAM \\
\hline 6108165 & Lerop 4 & 196900 & 353000 & 1.7 & $13.64 \pm 0.53$ & $1.01 \pm 0.04$ & $13.5 \pm 0.8$ & OK & CAM \\
\hline 6108166 & Molenveldweg 25 & 196650 & 352525 & 1.6 & $13.20 \pm 0.64$ & $1.01 \pm 0.04$ & $13.1 \pm 0.8$ & Likely OK & BSMAM \\
\hline
\end{tabular}

might indicate an origin in sandy braided systems. The sedimentary succession at level A resembles the fluvial to aeolian succession as described in the Meuse valley near Grubbenvorst (Kasse et al., 1995, photo 2; 2007). A partial co-functioning of the braided system and coversand deposition may have occurred. The absence of curved meander scars at the transition to older terraces might also point to deposition by straight or low-sinuosity channels during the formation of level A. Level A rapidly radiates in a downstream direction, which can be interpreted as an aggrading sandy alluvial fan that formed because of the gradient decrease in the confluence area of the Roer and the Meuse, along the eastern margin of the Meuse valley (Fig. 3b).

The single optical date of $15.5 \pm 1.1 \mathrm{ka}$ obtained from fluvial sediment $(210-300 \mu \mathrm{m})$ (Table 1: NCL-6108159, Stella Maris 3) indicates formation of level A during the final Late Pleniglacial (Fig. 4). Level A dips to the northwest in the direction of the Meuse valley and merges with Meuse terraces near Roermond (Van den Broek \& Maarleveld, 1963; Van den Berg \& Schwan, 1996). These Meuse terrace levels, covered by aeolian deposits, have been described previously (Mol et al., 1993; Kasse et al., 1995: level 1; Van den Berg \& Schwan, 1996: level 2; Van Huissteden \& Kasse, 2001). At Grubbenvorst, $28 \mathrm{~km}$ north of Roermond, Kasse et al. (2007) optically dated the fluvial to aeolian succession of terrace level 1 , including the Older Coversand I and Older Coversand II, separated by the Beuningen Gravel Bed. For the fluvial deposits, the obtained ages are between 29 and $25 \mathrm{ka}$, whereas overlying fluvio-aeolian deposits (Older Coversand I) were dated between 25 and $17 \mathrm{ka}$. West of the Meuse river, near Neer, this terrace was investigated by trenching to reconstruct the fault displacement rate along the Peel Boundary Fault (Van den Berg et al., 2002). The fluvial to aeolian succession of the foot wall, below the Beuningen Gravel Bed, was infrared stimulated luminescence (IRSL) / thermoluminescence (TL)-dated between $36.1 \pm 3.9 / 25.6 \pm 2.8 \mathrm{ka}$ and $16.4 \pm 2.5$
/ 16.4 $\pm 1.9 \mathrm{ka}$ (Frechen \& Van den Berg, 2002). Both studies indicate a Middle to Late Pleniglacial age. However, it cannot be excluded that level A is polygenetic. According to Van den Berg (1989), different terraces separated by inconspicuous scarps are present, which were formed during the Saalian (Caberg and Eisden Lanklaar Terraces) and Weichselian (Mechelen aan de Maas Terrace).

The Late Pleniglacial was characterised by cold conditions with mean winter temperatures of -25 to $-15^{\circ} \mathrm{C}$ and mean summer temperatures of 10 to $15^{\circ} \mathrm{C}$ (Renssen \& Isarin, 2001). In the Roer catchment and wider surroundings of the Lower Rhine Embayment and the Ardennes foothills the sparse vegetation (Hoek, 1997a) and continuous permafrost conditions (Vandenberghe \& Pissart, 1993; Kasse, 2002) resulted in a low soil permeability and overland flow during snow melt (Woo \& Winter, 1993). These factors caused a high sediment supply from the upstream catchment of the Roer in the Eifel mountains, which downstream, in the Roer Valley Graben, resulted in aggradation by a braided river system forming a low-angle alluvial fan in the Roer-Meuse confluence area. A decline of fluvial activity followed by aeolian deposition is inferred in the Roer valley (Fig. 6: units A2, A3). A similar evolution was also determined for several western and central European valleys (Schwan, 1987; Vandenberghe \& Van Huissteden, 1988; Bohncke et al., 1995; Van Huissteden \& Kasse, 2001; Vandenberghe et al., 2013; Zieliński et al., 2014; Kadlec et al., 2015) and was related to increasing climatic aridity during the Late Pleniglacial (Kasse, 1997, 2002; Kasse et al., 2007).

\section{Pleniglacial - Late-glacial fluvial transition (level A to $B$ )}

The biostratigraphy of the basal infill of several abandoned meanders in the more upstream part of level B (Figs 5 and 7) shows that the infill occurred during the Older Dryas and Allerød 
biozones (Figs 8-11), and indicates that the Roer river was a meandering river during the Older Dryas or even the Bølling period. The start of the channel fills is in close agreement with palynological results from site Posterholt where an Allerød age was established at the base of a channel fill (Bakels, 2017). Therefore, the channel pattern change from an aggradational, probably braided, system (level A), blanketed by coversands, to an incising meandering system (level B; Fig. 3) possibly occurred during the early Late-glacial or at the Pleniglacial to Late-glacial transition $(\sim 14.7 \mathrm{ka})$.

The Roer fluvial development echoes that of the Meuse system in central and northern Limburg between Roermond and Cuijck, although the start of the meandering phase in the Roer may be earlier than in the Meuse valley. In the Meuse valley most Late-glacial palaeomeanders have an Allerød or Younger Dryas basal infill (Kasse et al., 1995; Van den Berg \& Schwan, 1996; Huisink, 1997) although older fills have also been reported (Tebbens et al., 1999), indicating that the Meuse was a meandering system during and before the Allerød period. A transitional phase of pattern change from braided to meandering, as reported for the Meuse and Niers rivers (Kasse et al., 1995, 2005 respectively), was not observed in the Roer valley. The Meuse and Niers had a gradual or delayed fluvial response to the rapid warming at the start of the Late-glacial at $14.7 \mathrm{ka}$ of c. $700 \mathrm{ra}-$ diocarbon years, despite the abrupt change in temperature and precipitation (Kasse et al., 2005). The delayed response can be explained by reach-to-reach and catchment-to-catchment differences in the balance between discharge and sediment supply (Vandenberghe, 1995), which would be affected by the gradual migration of vegetation and associated stabilisation of the surface by vegetation and soil formation (Hoek, 2001). The pollen diagrams of the Roer valley (Figs 8-11) show that the vegetation was still rather open and characterised by heliophilous herbs, Poaceae and Betula.

Aggradation of the river valley by a braided system (level A) during the Late Pleniglacial was probably related to the snowmelt peak discharges, a frozen subsoil and high sediment supply (as a result of weathering and lack of vegetation). During the early Late-glacial, peak discharges probably decreased because of permafrost degradation and the resulting increased soil permeability. Because of higher winter temperatures and reduced snow cover, discharge became more regular, and as a consequence the braided system (level A) transformed into a meandering system (level B) because of reduced stream power (Van den Berg, 1995; Bogaart et al., 2003; Fig. 3) despite the floodplain slope increase. Lower floodplain gradients would also imply a reduction of stream power and channel-pattern changes from braided to meandering. However, the Roer valley gradient of meandering level B (c. $62 \mathrm{~cm} \mathrm{~km}^{-1}$ ) is higher than for level A (c. $\left.55 \mathrm{~cm} \mathrm{~km}^{-1}\right)$. Therefore, gradient changes cannot be responsible for the observed river system changes from braided to meandering. The gradual immigration of vegetation, start of soil formation and increasing cohesion of the surface resulted in a gradual decrease in sediment supply leading to incision by the Roer river, which is evident from the small terrace scarp (c. $2 \mathrm{~m}$ ) between levels A and B (Fig. 3).

Similar fluvial system changes have been described in central and northwestern Europe during this time interval (Kozarski, 1983; Kiden, 1991; Bohncke et al., 1995; Rose, 1995; Schirmer, 1995; Pastre et al., 2003; Starkel et al., 2007, 2015; Erkens et al., 2011; Meylemans et al., 2013; Turner et al., 2013). It has been postulated that the timing of the fluvial system transformation from braided to meandering is not uniform for all river systems but that it depends on the discharge, grain size, gradient and surrounding vegetation, which all influence sediment supply and river transport capacity. Turner et al. (2013) reported that changes in the Jeetzel river from a braided to an incised system even pre-dated the Late-glacial warming. They also stress the importance of the vegetation cover determining evapotranspiration, soil cohesion and sediment supply. According to Kasse et al. (2010), the earlier transition from braided to meandering in the Tisza river in Hungary, compared to northwestern and central European rivers, may be related to earlier vegetation development in southeastern Europe.

\section{Late-glacial meandering system (level B)}

The OSL dates from pointbar deposits and channel fills of level $B$ range between $16.0 \pm 1.1 \mathrm{ka}$ (NCL-6108160) and $12.7 \pm 0.7 \mathrm{ka}$ (NCL-6108162), indicating that fluvial activity and lateral migration by a meandering system probably occurred during the Late-glacial period (14.7-11.7 ka) (Fig. 4; Table 1). Due to the range of ages and the precision of the individual estimates, it is not possible to assign specific parts of level B to the BøllingAllerød interstadial or the Younger Dryas stadial without additional independent dating. The dates are in agreement with previous results obtained from channel fills on meandering level B (Hoek, 1997a, site RM0 3; Bakels, 2017). The sediments have been attributed to the Younger Dryas (biozone 3) supported by a radiocarbon date of $10,440 \pm 160 \mathrm{BP}(12,761-11,860 \mathrm{cal}$ BP; 0xcal 4.2) (Hoek, 1997b, p. 53). Meandering level B is locally overlain by parabolic dunes OSL-dated at $13.6 \pm 0.9 \mathrm{ka}$ (NCL-6108157; Bergerweg 16) and $0.85 \pm 0.05 \mathrm{ka}$ (NCL-6108156; Bergerweg 14) (see discussion below) (Fig. 4). Parabolic dune formation in the Roer valley probably occurred during the Younger Dryas stadial (12.9-11.7 ka), similar to the Meuse valley (Bohncke et al., 1993; Kasse et al., 1995). Therefore, meandering level B at location Bergerweg is older than the Younger Dryas, as also indicated by the OSL date of $14.1 \pm 0.8 \mathrm{ka}$ (NCL-6108158) from the fluvial sediments underlying the parabolic dune. However, this does not necessarily mean that level B was inactive during the Younger Dryas since younger meandering channels are present outside the dune complex (Figs 3 and 4). The optical dates of the meander pointbars and palynological results from the youngest meander fill Kitscherholz indicate that the Roer 
was a meandering system during the entire Late-glacial period, starting in the Bølling and continuing up to the Younger Dryas - Holocene transition.

Pollen diagrams Karken, Haaserdriesch and Geraerds (Figs 810) show an increase in trees, especially Betula, attributed to the Allerød biozone. An increase of Pinus, characteristic for the second part of the Allerød (PAZ 2b), was only observed at Karken (Fig. 8). The rare presence of pine can be explained by the location of the sites in the wide and wet valley (Fig. 5). In addition, shielding effects by Salix stands near the abandoned channels may have reduced the influx of Pinus pollen (Fig. 10). An increase in forest cover and associated increase in evapotranspiration could have resulted in lower bank-full discharges and reduced channel dimensions (Ward et al., 2008; Kasse et al., 2010). In the more upstream part of level B, smaller meanders in the axis of the valley seem to indicate a decrease in channel dimension (Fig. 5). However, in the downstream part this change was not observed (Fig. 4). The increase in vegetation cover will have reduced the sediment supply to the river, resulting in erosion of the river channel. Successive meander generations of level B are situated in a slightly lower position in the landscape, illustrating the tendency for gradual incision during meander formation (Fig. 4). The incision of the Meuse and Roer during the Late-glacial can be explained by the climate and vegetationcontrolled change in the discharge/sediment ratio, in combination with the long-term tectonic uplift of this southeastern part of the Roer Valley Graben (Van Balen et al., 2000) comparable to other river systems (e.g. Maddy et al., 2001). The Late-glacial incision and terrace formation cannot be explained by glacioisostatic movements as this region was probably subsiding due to forebulge collapse (Busschers et al., 2007).

Level B is characterised by several generations of palaeomeanders that show cross-cutting relationships and a tendency towards incision (Fig. 4). The optical dates indicate rapid lateral channel migration, pointbar and channel cut-off formation during the Late-glacial, despite the Late-glacial vegetation increase and increased soil cohesion. The presence of the Usselo Soil of Allerød age in northwestern Europe indeed indicates landscape stability outside floodplains (Kasse, 2002; Kaiser et al., 2009). The strong fluvial dynamics of the meandering system can be explained by (1) the sandy substrate and (2) increase of floodplain gradient due to downstream incision. The cut banks and the subsoil of the meanders consist mostly of fine to medium sand of level A (Fig. 6: cross section $\mathrm{AA}^{\prime}$ ). The non-cohesive character could have enhanced lateral migration of the meandering channels (Allen, 1965; Berendsen \& Stouthamer, 2001). The valley gradients of the successive levels $\mathrm{A}, \mathrm{B}$ and $\mathrm{C}$ show an increase from c. $55 \mathrm{~cm} \mathrm{~km}^{-1}$ to $75 \mathrm{~cm} \mathrm{~km}^{-1}$ (Van Bostelen \& Vreugdenhil, 2009). The upstream convergence of the valleygradient lines indicates a downstream control governed by incision by the Meuse during formation of level B during the Late-glacial (Kasse et al., 1995; Van den Berg \& Schwan, 1996; Huisink, 1997). This resulted in a local base-level lowering at the confluence of the Roer and the Meuse, leading to Roer incision that propagated upstream from the river mouth in the downstream part of the Roer valley. In addition, lateral migration of the Meuse to the east, in the Meuse-Roer confluence area during this period, might have shortened the downstream part of the Roer, thereby increasing the gradient of the Roer. Following the reduction in stream power due to the decrease in peak discharge from the Pleniglacial (level A) to the Late-glacial (level B), the gradual steepening of the gradient by incision generated an increase in stream power that may have caused intensified lateral migration and meandering on level B and in the Holocene floodplain (Holbrook \& Schumm, 1999). However, the increase in stream power apparently was insufficient to induce a transformation to a braided system. The headward incision since the start of the Late-glacial has resulted in upstream knickpoint migration of the present-day river up to c. $10 \mathrm{~km}$ southeast of the Dutch-German border. East of this point, clear terraces cannot be distinguished in the Roer valley.

\section{Younger Dryas impact on the Roer}

Although some delay may be present between the moment of channel abandonment and the first channel infill, the palynological results of the channel fills and the OSL dates of level $B$ indicate that a meandering system was active in the southern valley during the Late-glacial. As the basal part of the youngest channel fill (Kitscherholz) has been interpreted as the Younger Dryas biozone (Fig. 11), it is concluded that the meandering channel belt of level B was still active during the Younger Dryas. The southern course was probably abandoned during the late Younger Dryas or at the Younger Dryas to Holocene transition (see Holocene evolution of level C). In the pollen diagrams Haaserdriesch, Geraerds and Karken (Figs 810) the increase in grasses and heliophilous herbs indicates more open vegetation and unstable soil conditions during the Younger Dryas. Betula is the dominant tree species while Pinus is low. Empetrum (diagram Haaserdriesch) and Ephedra (diagram Karken) are characteristic elements of the Younger Dryas vegetation.

The Younger Dryas was characterised by low winter temperatures, discontinuous permafrost conditions and opening of the vegetation cover (Kasse, 1995a; Hoek, 1997a; Renssen, 2001). Lower evapotranspiration, more snow accumulation in winter and lower soil permeability due to permafrost or deep seasonal frost will have resulted in a more nival discharge regime with higher peak flood discharges and stream power than during the preceding Allerød period (Kasse et al., 1995; Huisink, 1997; Pastre et al., 2003; Dzieduszyńska et al., 2014). The start of meander fill Kitscherholz seems to indicate that the Roer was a meandering system during the Younger Dryas period. No clear channel-pattern change from meandering to braided has been found in the Late-glacial southern course of the Roer valley, in 
contrast to the larger rivers Meuse and Rhine (Berendsen et al., 1995; Kasse et al., 1995; Huisink, 1997; Erkens et al., 2011; Janssens et al., 2012). Intensive lateral meander migration in the northern course (level $\mathrm{C}$ ) during the Holocene may have erased possible traces of the Younger Dryas course in that area. Apparently the threshold value in stream power change was not crossed. In this respect the Roer resembles the Niers in Germany (Kasse et al., 2005), the Scheldt in Belgium (Kiden, 1991; Meylemans et al., 2013) and central European rivers like the Tisza in Hungary (Kasse et al., 2010) and Warta in Poland (Vandenberghe et al., 1994).

Although a valley-wide channel pattern change was not observed, some fluvial changes in the Roer valley might be related to the Younger Dryas cooling. In the downstream part of level B larger and deeper palaeomeanders are present near StekveldLerop (Figs 3 and 4) that indicate an increase in bank-full discharge, possibly during the Younger Dryas, which is comparable to the Niers valley (Kasse et al., 2005). The optical dates $(15.8 \pm 0.9$ and $13.5 \pm 0.8 \mathrm{ka})$ of the related meander pointbars, however, do not indicate a Younger Dryas age (Fig. 4; Table 1). The southeast-northwest-oriented straight lineament near Lerop, at an intermediate level between meandering levels B and C (Fig. 3), might represent a small terrace scarp formed by a straight, possibly braided, channel that could have been formed during the Younger Dryas. This interpretation seems to be supported by the optical date of $13.1 \pm 0.7 \mathrm{ka}$ (Lerop 9) indicating an Allerød or Younger Dryas age. However, the upstream continuation of this intermediate level could not be established. Both larger meanders and straight terrace fragment have lower elevations than the rest of level B (Figs 3 and 4). This indicates incision during their formation, possibly during the Younger Dryas, which is in accordance with the Younger Dryas fluvial incision in the Meuse valley (Kasse et al., 1995; Huisink, 1997).

The palaeochannel fills (Haaserdriesch, Geraerds and Karken) in the upstream part of level B show a lithological change from organic to clay deposition at the Allerød to Younger Dryas transition (Fig. 7). This probably indicates higher peak discharges in the Younger Dryas active channel and deposition of suspended material in the abandoned channels. A similar fluvial response with increased clay deposition during the Younger Dryas in abandoned channels of Allerød age and on terraces was described for the Meuse valley near Beugen and Bosscherheide (Bohncke et al., 1993; Kasse, 1995a) and in the Paris Basin in France (Pastre et al., 2003).

Parabolic dunes near Montfort, up to $10 \mathrm{~m}$ high, and associated deflation hollows (Fig. 3) have been found superposed on the undulating morphology of level A, and they locally overlie meander scars of level B (Van den Berg, 1989). The close spatial link of deflation hollows and downwind dune forms indicates that the dunes were formed by local deflation of terrace level A by southwesterly winds (Fig. 3). The possible cause for deflation may be related to the incision of the Meuse and the Roer during the Allerød and Younger Dryas in combination with a reduced vegetation cover during the Younger Dryas. The incision will have resulted in groundwater level lowering in the adjacent terrace level $\mathrm{A}$, making it vulnerable for deflation. In addition, the sandy character of level A (Fig. 6: cross section AA') provided good source material for deflation.

The parabolic dune complex at Bergerweg (sample 16) has been dated at $13.6 \pm 0.9 \mathrm{ka}$, indicating that dune formation occurred during the Late-glacial and possibly during the Younger Dryas stadial (12.9-11.7 ka) (Fig. 4; Table 1). Bergerweg 14 $(0.85 \pm 0.05 \mathrm{ka} / 1158 \pm 49 \mathrm{AD})$, taken from the same dune complex, can be explained by local remobilisation of the dune and drift-sand formation during the Middle Ages (Castel et al., 1989; Vandenberghe et al., 2013). Younger Dryas dune formation is in accordance with previous findings along the east bank of the Meuse between Roermond and Nijmegen (Bohncke et al., 1993; Kasse, 1995b; Michon \& Van Balen, 2005) and along the Schelde river between Antwerp and Bergen op Zoom (Vandenberghe et al., 2004). However, the formation of parabolic dunes in the Roer valley by local deflation of higher terraces contrasts with the genesis of the extensive Younger Dryas dune fields along the Meuse and Scheldt, which are attributed to deflation of sand from the then active Younger Dryas river braid plain and deposition in source-bordering (river) dunes on higher terraces east of the rivers (Bohncke et al., 1993; Kasse, 1995b).

\section{Holocene evolution (level C)}

The youngest OSL date $(12.7 \pm 0.7 \mathrm{ka})$ from pointbar sediment and thus meander activity on level B (Fig. 4) in combination with the start of the channel fill (i.e. meander abandonment) at Kitscherholz during the Younger Dryas and Preboreal (Figs 5 and 11), indicates that level B (southern branch) was abandoned approximately at the Younger Dryas to Holocene transition.

Levels B and C are separated by a clear terrace scarp of $c$. 4-5 $\mathrm{m}$ formed by incision of the Roer river (Figs 3 and 4). The downstream incision of the Roer was partly controlled by the incision of the Meuse as indicated by the steepening of the floodplain gradients at levels A, B and C. In addition, incision can be explained by a change in the discharge/sediment supply ratio related to the climatic amelioration and rapid vegetation response at the start of the Holocene (Hoek, 2001; Renssen \& Isarin, 2001). The pollen diagrams from the abandoned channels at level B show a rapid increase in arboreal pollen during the Early Holocene. Juniperus and Betula show a peak during the Preboreal (Figs 10 and 11: diagrams Haaserdriesch and Kitscherholz), followed by an increase in Pinus and Corylus during the Boreal (Figs 8 and 9: diagrams Geraerds and Karken) and Alnus and Tilia during the Atlanticum (Fig. 8: diagram Karken). The incision event and related lowering of the groundwater table is registered in the channel fills Geraerds and Karken by soil formation and a higher amount of indeterminable pollen in 
the top of the clay. In the pollen diagrams a hiatus is present since the Preboreal biozone is missing (Figs 8 and 9). In the deeper palaeochannel Haaserdriesch, the regional groundwater table lowering resulted in a drop in the local water level that is reflected by a lithological change from clay and gyttja to moss peat (Fig. 10).

The incision and level B abandonment by the Roer can further be bracketed by comparing biostratigraphical and OSL-dating results from level B (see above) and the Holocene floodplain level C. According to Janssens (2011, pollen diagrams Turfkoelen and Bennebroek), the oldest fills of abandoned meanders from level $\mathrm{C}$ date from the Preboreal and Boreal. These age estimates are in accordance with previous biostratigraphical results from Holocene floodplain sediments south of Melick where the Boreal (biozone 5) has been found (Hoek, 1997a, sites Melick and RMO 4). Therefore, floodplain incision, which had started during the formation of level B during the Allerød and Younger Dryas, intensified during the late Younger Dryas and early Preboreal. Since the Early Holocene sites occur along both valley borders, this indicates that both vertical incision and widespread lateral erosion occurred during this instability phase. The Early Holocene incision of the Roer is in agreement with previous results for northwest and central European rivers (Vandenberghe et al., 1994; Huisink, 1997; Starkel, 2002; Kasse et al., 2005, 2010; Erkens et al., 2011).

The abandonment of level B (southern branch) and incision of the Roer in a northern course (level C) indicates that probably two courses were simultaneously present during the Late-glacial (Fig. 3). It is unlikely that the Roer shifted from level B to level C by channel avulsion, due to the incised position of level B. However, little hard evidence is present for the Late-glacial northern course, except for a Late-glacial meander remnant west of Herkenbosch (Fig. 3). We suggest that most of the Late-glacial fluvial morphology in the northern branch was eroded by the lateral migration of the Holocene river.

\section{Trends in number of active channels}

The fluvial development over the studied time interval indicates a reduction of the number of channels and channel belts over the Pleniglacial with an aggrading braided system, to the Lateglacial with two incised meandering channel belts and finally to the Holocene with one deeply incised meandering channel belt. Similar channel-belt reductions have been described previously for the Niers, Oude IJssel and Rhine systems (Cohen, 2003; Kasse et al., 2005; Busschers et al., 2007; Hijma et al., 2009; Erkens et al., 2011; Janssens et al., 2012). It is suggested that during an incision phase the channel with the highest discharge erodes more rapidly, making a deeper channel and therefore reducing the flow in the smaller channel belts at the bifurcating point (Cohen, 2003; Erkens et al., 2009). The supposed mechanism would imply that the northern Roer branch was more important in terms of discharge. In addition, parabolic dune formation, probably during the Younger Dryas, may have obstructed the southern course of the Roer (Van Zuidam, 1980; Van den Berg, 1989; Fig. 3). Differential tectonic movements along the faults of the Roer Valley Graben could also explain the northward channel-belt shift (Fig. 1), as along one of the Rhine branches (Cohen, 2003). Along the Peel Boundary Fault (bounding the study area in the northeast) a $1 \mathrm{~m}$ displacement since the Younger Dryas has been established (Michon \& Van Balen, 2005), while no displacement has been observed along the southern Beegden Fault. This should have resulted in a northeastward tilt of the Roer Valley Graben towards the Peel Boundary Fault, possibly leading to a northward shift of the channel to the area of maximum subsidence. This proposed mechanism of northward block tilting and channel-incision competition was previously also postulated to explain parts of the Late-glacial and Early Holocene fluvial evolution of the Rhine-Meuse area (Cohen, 2003; Hijma et al., 2009). Finally, the northward shift may be related to collapse of the glacial forebulge during this period (Busschers et al., 2007). As the centre of the forebulge was situated towards the north, its collapse will have had a similar effect to the tilt of the Roer Valley Graben.

\section{Lithological trends}

Levels B and C are both characterised by fining-upward sequences which are comparable in thickness, indicating that the sequences were formed by laterally migrating meandering channels of similar dimensions and depth (Fig. 6: cross section AA'). However, some differences in the sedimentary successions have been observed. Level $\mathrm{C}$ has a coarse-grained, gravelly channel lag deposit and an overlying sequence dominated by sand and loam, while level B has a channel lag deposit with slightly gravelly, coarse sand and pointbar sediments dominated by sand (unit B2). The differences in grain size cannot be explained by differences in gradient and transport capacity, as the finergrained Holocene floodplain has a higher gradient than level B. The different character of the channel lag deposits may be related to the grain size of the substrate. The meanders of level $B$ eroded the sandy units $A 2 / A 3$ of level A, while the meanders of the more incised level $C$ eroded into the gravelly unit A1 of level A (Fig. 6: cross section AA'). The different lithological successions at levels $B$ and $C$ can further be explained by the formational time span of the levels and human activity. According to the optical dates and biostratigraphical results, level B was formed in a geologically short period of 3000 years covering the Late-glacial (Fig. 4). Limited time was available for fine-grained overbank deposition on the pointbar systems and in the abandoned meander channels. The wealth of palaeomeanders and meander cut-offs on level B shows that lateral migration rates of the meandering channels were high, eroding previously deposited overbank fines, and therefore preservation of overbank fines was limited (Hobo et al., 2014). In the abandoned channels of level $B$, fine-grained channel fills are thin 
and for that reason the palaeochannels are easily visible as geomorphological features in the present-day landscape (Fig. 4). Level $C$, on the other hand, covers the longer time span of the Holocene, and therefore deposition of suspended material on the floodplain has formed thick fine-grained floodplain and channel-fill units (Fig. 6: cross section $\mathrm{AA}^{\prime}$, units $\mathrm{C} 3 / \mathrm{C} 4$ ). In addition, human activity, deforestation and agriculture may have increased erosion in the catchment of the Roer, leading to a higher suspended load and increased rates of loam deposition in the floodplain (Janssens, 2011). Neolithic occupation was reported on the Aldenhoven loess plateau in the Roer catchment (Kalis \& Bunnik, 1990). However, the impact on river systems was still low during the Neolithic, probably because of localised deforestation and limited connectivity of arable fields with the river floodplain as established for the Dijle river by Broothaerts et al. (2014a). From the Bronze Age onwards, human impact on the Roer landscape increased (Bunnik, 1999) and increased loam deposition is reported in river valleys in central Belgium (Broothaerts et al., 2014a). Especially during the Roman period and the Middle Ages the impact of man on the landscape was strong, which was reflected by high sedimentation rates in alluvial fans and floodplains in the southern Netherlands and central Belgium (De Moor et al., 2008; Broothaerts et al., 2014b)

\section{Conclusions}

The last glacial to interglacial transition is characterised by rapid climate change and related environmental impact on the landscape and vegetation. In this paper, fluvial channel pattern changes, incision trends and vegetation development in the Roer valley in the southeastern Netherlands and western Germany have been presented for the Late Pleniglacial, Late-glacial and Early Holocene periods. We conclude that:

- two phases of terrace formation have occurred coinciding with the Pleniglacial to Late-glacial and Younger Dryas to Holocene transitions. The development is explained by changes in the discharge/sediment ratio, related to climate and vegetation change, and by the downstream control of the incising Meuse river.

- the number of channels reduced stepwise from a multichannel braided system in the Pleniglacial, to a twofold meander-belt system in the Late-glacial and a single-channel meandering system in the Holocene.

- the Roer changed from an aggrading braided to an incising meandering system at the Pleniglacial to Lateglacial transition. During the Late-glacial a dynamic and gradually incising meandering system established in the Roer valley as indicated by OSL dating. The sandy substratum and higher river gradient in the downstream part of the Roer, related to the incision of the Meuse, promoted lateral meander migration.
- a fluvial system response related to the Younger Dryas cooling could not be established conclusively. The youngest Late-glacial meanders are larger, and a small, straight terrace fragment has been preserved locally. Holocene lateral meander migration and incision might have erased the Younger Dryas fluvial landforms. Incision, groundwater level lowering and opening of the vegetation cover resulted in localised deflation of the sandy Pleniglacial terrace and parabolic dune formation by southwesterly winds.

- the Younger Dryas to Early Holocene transition is reflected by enhanced incision, causing terrace formation and preservation of the glacial to interglacial fluvial record. Incision was induced by forest recovery, reduced sediment supply and the lowering base level of the Meuse.

- the forcing factors of fluvial system change in the Roer valley are climate (discharge and vegetation change) and downstream base-level control by the Meuse. The sandy subsurface lithology might have played a role in the rapid meander migration.

\section{Acknowledgements}

The authors thank Toine van Bostelen and Marlies Janssens for collecting the field data used in this study. Kim Cohen and Henk Weerts are thanked for constructive reviews that improved the paper.

\section{References}

Allen, J.R.L., 1965. A review of the origin and characteristics of recent alluvial sediments. Sedimentology 5: 89-191.

Bakels, C., 2017. Posterholt, a Late Pleistocene - Holocene record of the vegetation history in and around the valley of the Vlootbeek, a tributary of the river Meuse (southeastern Netherlands). Netherlands Journal of Geosciences / Geologie en Mijnbouw, this issue.

Berendsen, H.J.A. \& Stouthamer, E., 2001. Palaeogeographic development of the Rhine-Maas Delta, the Netherlands. Van Gorcum (Assen): 270 pp.

Berendsen, H., Hoek, W. \& Schorn, E., 1995. Late Weichselian and Holocene river channel changes of the rivers Rhine and Meuse in the Netherlands (Land van Maas en Waal). In: Frenzel, B. (ed.): European river activity and climatic change during the Lateglacial and early Holocene. European Science Foundation project 'European Palaeoclimate and man', special issue 9, Paläoklimaforschung / Palaeoclimate Research 14: 151-172.

Bodemkaart van Nederland, 1972. Blad 57 0ost Valkenswaard, Blad 58 West Roermond, schaal 1:50.000. Stichting voor Bodemkartering (Wageningen): $172 \mathrm{pp}$.

Bogaart, P.W., Van Balen, R.T., Kasse, C. \& Vandenberghe, J., 2003. Processbased modelling of fluvial system response to rapid climate change II: application to the river Maas during the Last Glacial-Interglacial transition. Quaternary Science Reviews 22: 2097-2110. 
Bohncke, S. \& Wijmstra, L., 1988. Reconstruction of Late-Glacial lake-level fluctuations in The Netherlands based on palaeobotanical analyses, geochemical results and pollen-density data. Boreas 17: 403-425.

Bohncke, S.J.P., Vandenberghe, J. \& Huijzer, A.S., 1993. Periglacial palaeoenvironments during the Late Glacial in the Maas valley, the Netherlands. Geologie en Mijnbouw 72: 193-210.

Bohncke, S., Kasse, C. \& Vandenberghe, J., 1995. Climate induced environmental changes during the Vistulian Lateglacial at Żabinko, Poland. Quaestiones Geographicae 4 (special issue): 43-64.

Bøtter-Jensen, L., Andersen, C.E., Duller, G.A.T. \& Murray, A.S., 2003. Developments in radiation, stimulation and observation facilities in luminescence measurements. Radiation Measurements 37: 535-541.

Bridge, J.S., 1985. Paleochannel patterns inferred from alluvial deposits: a critical evaluation. Journal of Sedimentary Petrology 55: 579-589.

Broothaerts, N., Verstraeten, G., Kasse, C., Bohncke, S., Notebaert, B. \& Vandenberghe, J., 2014a. Reconstruction and semi-quantification of human impact in the Dijle catchment, central Belgium: a palynological and statistical approach. Quaternary Science Reviews 102: 96-110.

Broothaerts, N., Verstraeten, G., Kasse, C., Bohncke, S., Notebaert, B. \& Vandenberghe, J., 2014b. From natural to human-dominated floodplain geoecology - a Holocene perspective for the Dijle catchment. Anthropocene 8: 46-58.

Bunnik, F., 1999. Vegetationsgeschichte der lössbörden zwischen Rhein und Maas, von der Bronzezeit bis in die frühe Neuzeit. PhD Thesis, Universiteit Utrecht: $194 \mathrm{pp}$.

Busschers, F.S., Kasse, C., Van Balen, R.T., Vandenberghe, J., Cohen, K.M., Weerts, H.J.T., Wallinga, J., Johns, C., Cleveringa, P. \& Bunnik, F.P.M., 2007. Late Pleistocene evolution of the Rhine in the southern North-Sea Basin: imprints of climate change, sea-level oscillations and glacio-isostacy. Quaternary Science Reviews 26: 3216-3248.

Castel, I., Koster, E. \& Slotboom, R., 1989. Morphogenetic aspects and age of Late Holocene eolian drift sands in Northwest Europe. Zeitschrift für Geomorphologie 33: 1-26.

Cohen, K.M., 2003. Differential subsidence within a coastal prism: Late-Glacial - Holocene tectonics in the Rhine-Meuse delta, The Netherlands. PhD Thesis, Utrecht University (Utrecht), Netherlands Geographical Studies 316: 1172.

Cohen, K.M., Stouthamer, E. \& Berendsen, H.J.A., 2002. Fluvial deposits as a record for Late Quaternary neotectonic activity in the Rhine-Maas delta, the Netherlands. Netherlands Journal of Geosciences / Geologie en Mijnbouw 81: 389-405.

Cunningham, A.C. \& Wallinga, J., 2010. Selection of integration time-intervals for quartz OSL decay curves. Quaternary Geochronology 5: 657-666.

Cunningham, A.C. \& Wallinga, J., 2012. Realizing the potential of fluvial archives using robust OSL chronologies. Quaternary Geochronology 12: 98-106.

Cunningham, A.C., Wallinga, J. \& Minderhoud, P.S.J., 2011. Expectations of scatter in equivalent-dose distributions when using multi-grain aliquots for OSL dating. Geochronometria 38: 424-431.

De Moor, J.J.W., Kasse, C., Van Balen, R., Vandenberghe, J. \& Wallinga, J., 2008. Human and climate impact on catchment development during the Holocene Geul River, the Netherlands. Geomorphology 98: 316-339.

Duller, G.A.T., 2003. Distinguishing quartz and feldspar in single grain luminescence measurements. Radiation Measurements 37: 161-165.
Dzieduszyńska, D.A., Kittel, P., Petera-Zganiacz, J., Brooks, S.J., Korzeñ, K., Krapiec, M., Pawłowski, D., Płaza, D.K., Płóciennik, M., Stachowicz-Rybka, R. \& Twardy, J., 2014. Environmental influence on forest development and decline in the Warta River valley (Central Poland) during the Late Weichselian. Quaternary International 324: 99-114.

Erkens, G., Dambeck, R., Volleberg, K.P., Bouman, M.T.I.J., Bos, J.A.A., Cohen, K.M., Wallinga, J. \& Hoek, W.Z., 2009. Fluvial terrace formation in the northern Upper Rhine Graben during the last 20000 years as a result of allogenic controls and autogenic evolution. Geomorphology 103: 476-495.

Erkens, G., Hoffmann, T., Gerlach, R. \& Klostermann, J., 2011. Complex fluvial response to Late Glacial and Holocene allogenic forcing in the Lower Rhine Embayment (Germany). Quaternary Science Reviews 30: 611-627.

Faegri, K. \& Iversen, J., 1989. Textbook of Pollen Analysis, 4th edition. Wiley \& Sons (Chichester): $328 \mathrm{pp}$.

Frechen, M. \& Van den Berg, M., 2002. The coversands and timing of Late Quaternary earthquake events along the Peel Boundary Fault in the Netherlands. Netherlands Journal of Geosciences / Geologie en Mijnbouw 81: 61-70.

Galbraith, R.F., Roberts, R.G., Laslett, G.M., Yoshida, H. \& Olley, J.M., 1999. Optical dating of single and multiple grains of quartz from Jinmium rock shelter, northern Australia: Part I, experimental design and statistical models. Archaeometry 41: 339-364.

Grimm, E., 1992. TILIA and TILIA-graph: pollen spreadsheet and graphics programs. Programs and Abstracts, 8th International Palynological Congress, Aixen-Provence: 56.

Hijma, M.P., Cohen, K.M., Hoffmann, G., Van der Spek, A. \& Stouthamer, E., 2009. From river valley to estuary: the evolution of the Rhine mouth in the early to middle Holocene (western Netherlands, Rhine-Maas delta). Netherlands Journal of Geosciences / Geologie en Mijnbouw 88: 13-53.

Hobo, N., Makaske, B., Wallinga, J. \& Middelkoop, H., 2014. Reconstruction of eroded and deposited sediment volumes of the embanked river Waal, the Netherlands, for the period AD 1631-present. Earth Surface Processes and Landforms 39: 1301-1318.

Hoek, W.Z., 1997a. Palaeogeography of Lateglacial vegetations. Aspects of Lateglacial and Early Holocene vegetation, abiotic landscape, and climate in the Netherlands. PhD Thesis, Vrije Universiteit Amsterdam (Amsterdam): 147 pp.

Hoek, W.Z., 1997b. Atlas to Palaeogeography of Lateglacial vegetations. Maps of Lateglacial and Early Holocene landscape and vegetation in The Netherlands, with an extensive review of available palynological data. PhD Thesis, Vrije Universiteit Amsterdam (Amsterdam): 165 pp.

Hoek, W.Z., 2000. Abiotic landscape and vegetation patterns in the Netherlands during the Weichselian Late Glacial. Netherlands Journal of Geosciences / Geologie en Mijnbouw 79: 497-509.

Hoek, W.Z., 2001. Vegetation response to the $\sim 14.7$ and $\sim 11.5$ ka cal. BP climate transitions: is vegetation lagging climate? Global and Planetary Change 30: 103-115.

Holbrook, J. \& Schumm, S.A., 1999. Geomorphic and sedimentary response of rivers to tectonic deformation; a brief review and critique of a tool for recognizing subtle epeirogenic deformation in modern and ancient settings. Tectonophysics 305: 287-306.

Houben, $\boldsymbol{P}_{.}, 2003$. Spatio-temporally variable response of fluvial systems to Late Pleistocene climate change: a case study from central Germany. Quaternary Science Reviews 22: 2125-2140. 
Huisink, M., 1997. Late Glacial sedimentological and morphological changes in a lowland river as a response to climatic change: the Maas, the Netherlands. Journal of Quaternary Science 12: 209-223.

Isarin, $\boldsymbol{R}$. \& Bohncke, S., 1999. Mean July temperatures during the Younger Dryas in Northwestern and Central Europe as inferred from climate indicator plant species. Quaternary Research 51: 158-173.

Janssens, M.M., 2011. Holocene floodplain development of the river Rur: allogenic or autogenic forcing mechanisms? Master thesis, Vrije Universiteit Amsterdam (Amsterdam): 53 pp.

Janssens, M.M., Kasse, C., Bohncke, S.J.P., Greaves, H., Cohen, K.M., Wallinga, J. \& Hoek, W.Z., 2012. Climate-driven fluvial development and valley abandonment at the last glacial-interglacial transition (Oude IJssel-Rhine, Germany). Netherlands Journal of Geosciences / Geologie en Mijnbouw 91: 3762.

Kadlec, J., Kocurek, G., Mohrig, D., Shinde, D.P., Murari, M.K., Varma, V., Stehlík, F., Beneš, V. \& Singhvi, A.K., 2015. Response of fluvial, aeolian, and lacustrine systems to late Pleistocene to Holocene climate change, Lower Moravian Basin, Czech Republic. Geomorphology 232: 193208.

Kaiser, K., Hilgers, A., Schlaak, N., Jankowski, M., Kühn, P., Bussemer, S. \& Przegiętka, K., 2009. Palaeopedological marker horizons in northern central Europe: characteristics of Lateglacial Usselo and Finow soils. Boreas 38: 591609.

Kalis, A.J. \& Bunnik, F.P.M., 1990. Holozäne Vegetationsgeschichte in der westlichen niederrheinischen Bucht. In: Schirmer, W. (ed.): Rheingeschichte zwischen Mosel und Maas. J. Wegener (Dormagen): 266-272.

Kasse, C., 1995a. Younger Dryas cooling and fluvial response (Maas River, the Netherlands) (extended abstract). Geologie en Mijnbouw 74: 251-256.

Kasse, C., 1995b. Younger Dryas climatic changes and aeolian depositional environments. In: Troelstra, S.R., Van Hinte, J.E. \& Ganssen, G.M. (eds): The Younger Dryas. Koninklijke Nederlandse Akademie van Wetenschappen, Verhandelingen, Afd. Natuurkunde, Eerste Reeks, deel 44. North-Holland (Amsterdam): 27-31.

Kasse, C., 1997. Cold-climate aeolian sand-sheet formation in North-Western Europe (c. 14-12.4 ka); a response to permafrost degradation and increased aridity. Permafrost and Periglacial Processes 8: 295-311.

Kasse, C., 2002. Sandy aeolian deposits and environments and their relation to climate during the Last Glacial Maximum and Lateglacial in northwest and central Europe. Progress in Physical Geography 26: 507-532.

Kasse, K., Vandenberghe, J. \& Bohncke, S., 1995. Climate change and fluvial dynamics of the Maas during the late Weichselian and early Holocene. In: Frenzel, B. (ed.): European river activity and climatic change during the Lateglacial and early Holocene. European Science Foundation project 'European Palaeoclimate and Man', special issue 9, Paläoklimaforschung / Palaeoclimate Research 14: 123-150.

Kasse, C., Hoek, W.Z., Bohncke, S.J.P., Konert, M., Weijers, J.W.H., Cassee, M.L. \& Van der Zee, R.M., 2005. Late Glacial fluvial response of the Niers-Rhine (western Germany) to climate and vegetation change. Journal of Quaternary Science 20: 377-394.

Kasse, C., Vandenberghe, D., De Corte, F. \& Van den haute, P., 2007. Late Weichselian fluvio-aeolian sands and coversands of the type locality Grubbenvorst (southern Netherlands): sedimentary environments, climate record and age. Journal of Quaternary Science 22: 695-708.
Kasse, C., Bohncke, S.J.P. Vandenberghe, J. \& Gábris, G., 2010. Fluvial style changes during the last glacial-interglacial transition in the middle Tisza valley (Hungary). Proceedings of the Geologists' Association 121: 180-194.

Kiden, P., 1991. The Lateglacial and Holocene evolution of the Middle and Lower River Scheldt, Belgium. In: Starkel, L., Gregory, K.J. \& Thornes, J.B. (eds): Temperate palaeohydrology. John Wiley and Sons (Chichester): 283-299.

Kiss, T., Hernesz, P., Sümeghy, B., Györgyövics, K. \& Sipos, G., 2015. The evolution of the Great Hungarian Plain fluvial system - fluvial processes in a subsiding area from the beginning of the Weichselian. Quaternary International 388: 142-155.

Kozarski, S., 1983. River channel changes in the middle reach of the Warta valley, Great Poland lowland. Quaternary Studies in Poland 4: 159-169.

Maddy, D., Bridgland, D. \& Westaway, R., 2001. Uplift-driven valley incision and climate-controlled river terrace development in the Thames Valley, UK. Quaternary International 79: 23-36.

Meylemans, E., Bogemans, F., Stormea, A., Perdaen, Y., Verdurmen, I. \& Deforce, K., 2013. Lateglacial and Holocene fluvial dynamics in the Lower Scheldt basin (N-Belgium) and their impact on the presence, detection and preservation potential of the archaeological record. Quaternary International 308-309: 148-161.

Michon, L. \& Van Balen, R.T., 2005. Characterization and quantification of active faulting in the Roer valley rift system based on high precision digital elevation models. Quaternary Science Reviews 24: 457-474.

Mol, J., Vandenberghe, J., Kasse, K. \& Stel, H., 1993. Periglacial microjointing and faulting in Weichselian fluvio-aeolian deposits. Journal of Quaternary Science 8: $15-30$.

Moore, P.D., Webb, J.A. \& Collinson, M.E., 1991. Pollen analysis, 2nd edition. Blackwell Scientific Publications (0xford): 216 pp.

Murray, A.S. \& Wintle, A.G., 2000. Luminescence dating of quartz using an improved single-aliquot regenerative-dose protocol. Radiation Measurements 32: 57-73.

Murray, A.S. \& Wintle, A.G., 2003. The single aliquot regenerative dose protocol: potential for improvements in reliability. Radiation Measurements 37: 377381.

Panin, A. \& Matlakhova, E., 2015. Fluvial chronology in the East European Plain over the last $20 \mathrm{ka}$ and its palaeohydrological implications. Catena 130: 46-61.

Pastre, J.-F., Limondin-Lozouet, N., Leroyer, C., Ponel, P. \& Fontugne, M. 2003. River system evolution and environmental changes during the Lateglacial in the Paris Basin (France). Quaternary Science Reviews 22: 2177-2188.

Pons, L.J., 1957. De geologie, de bodemvorming en de waterstaatkundige ontwikkeling van het Land van Maas en Waal en een gedeelte van het Rijk van Nijmegen. Mededelingen Stichting Bodemkartering, Bodemkundige Studies 3: $156 \mathrm{pp}$.

Renssen, H., 2001. The climate in The Netherlands during the Younger Dryas and Preboreal: means and extremes obtained with an atmospheric general circulation model. Geologie en Mijnbouw / Netherlands Journal of Geosciences 80: 19-30.

Renssen, H. \& Isarin, R.F.B., 2001. The two major warming phases of the last deglaciation at $\sim 14.7$ and $\sim 11.5 \mathrm{ka}$ cal BP in Europe: climate reconstructions and AGCM experiments. Global and Planetary Change 30: 117-153.

Rose, J., 1995. Lateglacial and early Holocene river activity in lowland Britain. In: Frenzel, B. (ed.): European river activity and climatic change during the Lateglacial and early Holocene. European Science Foundation project 'Euro- 
pean Palaeoclimate and $\mathrm{Man}^{\prime}$, special issue 9, Paläoklimaforschung / Palaeoclimate Research 14: 51-74.

Schalich, J., 1968. Die Spätpleistozäne und Holozäne Tal- und Bodenentwicklung an der mittleren Rur. Fortschritte Geologie Rheinland und Westfalen 16: 339 370.

Schirmer, W., 1995. Valley bottoms in the late Quaternary. Zeitschrift für Geomorphologie, Neue Folge, Supplement-Band 100: 27-51.

Schokker, J., Cleveringa, P., Murray, A.S., Wallinga, J. \& Westerhoff, W.E., 2005. An OSL dated Middle and Late Quaternary sedimentary record in the Roer Valley Graben (southeastern Netherlands). Quaternary Science Reviews 24: 22432264.

Schwan, J., 1987. Sedimentologic characteristics of a fluvial to aeolian succession in Weichselian Talsand in the Emsland (F.R.G.). Sedimentary Geology 52: 273298.

Sevink, J., Koster, E.A., Van Geel, B. \& Wallinga, J., 2013. Drift sands, lakes, and soils: the multiphase Holocene history of the Laarder Wasmeren area near Hilversum, the Netherlands. Netherlands Journal of Geosciences / Geologie en Mijnbouw 92: 243-266.

Starkel, L., 2002. Younger Dryas - Preboreal transition documented in the fluvial environment of Polish rivers. Global and Planetary Change 35: 157-167.

Starkel, L., Gębica, P. \& Superson, J., 2007. Last Glacial - Interglacial cycle in the evolution of river valleys in southern and central Poland. Quaternary Science Reviews 26: 2924-2936.

Starkel, L., Michczyńska, D.J., Gębica, P., Kiss, T., Panin, A. \& Perşoiu, I., 2015 Climatic fluctuations reflected in the evolution of fluvial systems of Central-Eastern Europe (60-8 ka cal BP). Quaternary International 388: 97118.

Tebbens, L.A., Veldkamp, A., Westerhoff, W. \& Kroonenberg, S.B., 1999. Fluvial incision and channel downcutting as a response to Lateglacial and Early Holocene climate change: the lower reach of the River Meuse, The Netherlands. Journal of Quaternary Science 14: 59-75.

Turner, F., Tolksdorf, J.F., Viehberg, F., Schwalb, A., Kaiser, K., Bittmann, F., von Bramann, U., Pott, R., Staesche, U., Breest, K. \& Veil, S., 2013. Lateglacial/early Holocene fluvial reactions of the Jeetzel river (Elbe valley, northern Germany) to abrupt climatic and environmental changes. Quaternary Science Reviews 60: 91-109.

Van Balen, R.T., Houtgast, R.F., Van der Wateren, F.M., Vandenberghe, J. \& Bogaart, P.W., 2000. Sediment budget and tectonic evolution of the Meuse catchment in the Ardennes and the Roer Valley Rift System. Global and Planetary Change 27: 113-130.

Van Balen, R.T., Houtgast, R.F. \& Cloetingh, S.A.P.L., 2005. Neotectonics of The Netherlands: a review. Quaternary Science Reviews 24: 439-454.

Van Bostelen, J.A. \& Vreugdenhil, M., 2009. De evolutie van de Roer in het Laat Glaciaal en Holoceen. Bachelorthesis Vrije Universiteit, Amsterdam: 102 pp.

Van den Berg, J.H., 1995. Prediction of alluvial channel pattern of perennial rivers. Geomorphology 12: 259-279.

Van den Berg, M.W., 1989. Toelichting op kaartblad 59 Genk, 60 Sittard, 61 Maastricht, 62 Heerlen. Geomorfologische kaart van Nederland 1:50.000. Staring Centrum Wageningen, Rijks Geologische Dienst (Haarlem): 33 pp.

Van den Berg, M.W. \& Schwan, J.C.G., 1996. Millennial cyclicity in Weichselian Late Pleniglacial to Early Holocene fluvial deposits of the river Maas in the southern Netherlands. In: Van den Berg, M.W.: Fluvial sequences of the Maas: a 10-Ma record of neotectonics and climatic change at various time scales. $\mathrm{PhD}$ Thesis, Wageningen University (Wageningen): 99-121.

Van den Berg, M., Vanneste, K., Dost, B., Lokhorst, A., Van Eijk, M. \& Verbeeck, $K ., 2002$. Paleoseismic investigations along the Peel Boundary Fault: geological setting, site selection and trenching results. Netherlands Journal of Geosciences / Geologie en Mijnbouw 81: 39-60.

Vandenberghe, D., Kasse, C., Hossain, S.M., De Corte, F., Van den haute, P., Fuchs, M. \& Murray, A.S., 2004. Exploring the method of optical dating and comparison of optical and $14 \mathrm{C}$ ages of Late Weichselian coversands in the southern Netherlands. Journal of Quaternary Science 19: 7386.

Vandenberghe, D.A.G., Derese, C., Kasse, C. \& Van den haute, P., 2013. Late Weichselian (fluvio-)aeolian sediments and Holocene drift-sands of the classic type locality in Twente (E Netherlands): a high-resolution dating study using optically stimulated luminescence. Quaternary Science Reviews 68: 96113.

Vandenberghe, J., 1995. Timescales, climate and river development. Quaternary Science Reviews 14: 631-638.

Vandenberghe, J., 2008. The fluvial cycle at cold-warm-cold transitions in lowland regions: a refinement of theory. Geomorphology 98: 275-284.

Vandenberghe, J. \& Pissart, A., 1993. Permafrost changes in Europe during the Last Glacial. Permafrost and Periglacial Processes 4: 121-135.

Vandenberghe, J. \& Van Huissteden, J., 1988. Fluvio-aeolian interaction in a region of continuous permafrost. 5th International Conference on Permafrost, Trondheim, Norway. Proceedings: 876-881.

Vandenberghe, J., Kasse, C., Bohncke, S.J.P. \& Kozarski, S., 1994. Climaterelated river activity at the Weichselian-Holocene transition: a comparative study of the Warta and Maas rivers. Terra Nova 6: 476-485.

Van den Broek, J.M.M. \& Maarleveld, G.C., 1963. The Late Pleistocene terrace deposits of the Meuse. Mededelingen Geologische Stichting, Nieuwe Serie 16: 13-24.

Van den Broek, J.M.M. \& Van der Marel, H.W., 1964. De alluviale gronden van de Maas, de Roer en de Geul in Limburg. Mededelingen van de Stichting voor Bodemkartering, Bodemkundige Studies 7 (Wageningen): 83 pp.

Van Huissteden, J. \& Kasse, C., 2001. Detection of rapid climate change in the Last Glacial fluvial successions in The Netherlands. Global and Planetary Change 28: 319-339.

Van Zuidam, R.A., 1980. Het Meinweggebied en Roergebied. Een tektonisch en eolisch beïnloed terrassenlandschap nabij Roermond (Midden Limburg). Koninklijk Nederlands Aardrijkskundig Genootschap, Geografisch Tijdschrift, Nieuwe reeks 14: 120-133.

Vreugdenhil, M., 2011. Fluvial and vegetational development during the Late Pleniglacial, Lateglacial and Holocene in the Rur valley. Master thesis, Vrije Universiteit Amsterdam (Amsterdam): $53 \mathrm{pp}$.

Ward, P.J., Renssen, H., Aerts, J.C.J.H., Van Balen, R.T. \& Vandenberghe, J., 2008. Strong increases in flood frequency and discharge of the River Meuse over the late Holocene: impacts of long-term anthropogenic land use change and climate variability. Hydrology and Earth System Sciences 12: 159175.

Woo, M.-K. \& Winter, T.C., 1993. The role of permafrost and seasonal frost in the hydrology of northern wetlands in North America. Journal of Hydrology 141: 5-31. 
Zieliñski, P., Sokołowski, R. J., Fedorowicz, S. \& Zaleski, I., 2014. Periglacial structures within fluvioaeolian successions of the end of the Last Glaciation examples from SE Poland and NW Ukraine. Boreas 43: 712-721.

Zuidhoff, F.S. \& Huizer, J. (eds.) 2015. De noordelijke Maasvallei door de eeuwen heen. Vijftienduizend jaar landschapsdynamiek tussen Roermond en Mook. ADC Monografie 19 (Amersfoort): $490 \mathrm{pp}$.

\section{Appendix: Description of the cross sections and pollen diagrams}

\section{Cross section Karken}

This cross section is situated over an abandoned meander along the right bank of level B (Fig. 5). The channel fill consists of gravelly sand overlain by channel and pointbar sands (Fig. 7). Its morphology shows in-channel bars and two scour pools (cores $1,2,5)$. The fine-grained fill of the pools starts with loamy sand and clay followed by gyttja and oxidised peat. Overlying the peat, clay has been found with traces of soil formation at the top, testifying to a period of non-deposition. Peaty clays were deposited later over the width of the palaeochannel. Coring 5 has been sampled for pollen analysis (Fig. 8).

Zone 1 (145-123 cm; clay) shows low arboreal pollen and high values in Poaceae and heliophilous herbs, in particular Artemisia and Asteraceae. Combined with the presence of Empetrum and Saxifraga, this indicates a relatively cold and dry period. The presence of Corylus, Alnus, Quercus and Tertiary pollen in the clastic basal fill of the channel can be attributed to reworking of older sediments. This zone probably reflects the Older Dryas biozone (PAZ 1c; pollen zones according to Hoek, 1997a).

Zone 2 (123-91 cm; gyttja) is characterised by a rise in Betula up to $60 \%$, wetland herbs and aquatics. Koenigia is present and, as a typical arctic-alpine species, it is associated with the Late-glacial. Therefore, this zone can be attributed to the $\mathrm{Be}$ tula phase of the Allerød (PAZ 2a), rather than the start of the Holocene. Both vegetation and lithology indicate warmer and wetter conditions and higher lake level in the abandoned meander (Bohncke \& Wijmstra, 1988; Hoek, 1997a).

Zone 3 (91-82 cm; oxidised peat) shows an increase in $P i$ nus, a decrease in grasses and low values of aquatic species. The lithological change from gyttja to peat indicates lower water levels and a change from open water to a riparian environment. The increase in Pine is characteristic for the Pine-phase of the Allerød and might be a response to increased continentality (Hoek, 1997a; PAZ 2b). The presence of Typha latifolia points to summer temperatures above $13^{\circ} \mathrm{C}$ (Isarin \& Bohncke, 1999).

Zone 4 (82-77 cm; clay) shows a decrease in arboreal pollen, and an increase in Poaceae and heliophilous herbs, like Potentilla, Brassicaceae and Asteraceae, indicating opening of the vegetation probably related to climate deterioration. Steppe elements, like Ephedra, are typical for the Younger Dryas (PAZ 3). The presence of Carya and Quercus and the clastic character of the sediment suggest reworking of sediment in the upstream catchment.

Zone 5 (77-70 cm; clay with soil formation) shows a decrease in Poaceae and upland herbs, a strong increase in Pinus and Corylus and low values of Quercus. The presence of Corylus is characteristic for the Boreal (PAZ 5), indicating that the Preboreal is missing in this diagram. This hia- tus may reflect a water-level drop with associated soil formation in the Karken palaeochannel, as indicated by high values of indeterminable and corroded pollen. Groundwater level lowering was possibly related to incision of the active channel at the Younger Dryas to Holocene transition (see discussion). The upper part of zone $5(70-62 \mathrm{~cm}$; peat) is characterised by high values of Alnus, Corylus and Tilia, which indicates the Atlantic period of the Holocene. Low values of Carpinus may even suggest a Subatlantic age for the upper part of the diagram, although anthropogenic indicators have not been observed.

\section{Cross section Geraerds}

Cross section Geraerds has been made over a meander scar of level B, $1.5 \mathrm{~km}$ southeast of Posterholt (Fig. 5). A channel lag deposit at c. $29 \mathrm{~m}$ a.s.l. is overlain by medium-grained, channel bar and pointbar sands (Fig. 7). The channel was first filled with loam and clay after channel abandonment, gradually grading into gyttja representing shallow lake conditions (core 77 78). The gyttja is sharply overlain by a clay layer representing increased flooding of the palaeomeander by a nearby active channel. As in Karken, the top of the clay has been influenced by soil formation and a hiatus can be assumed at that level. The upper part of the fill consists of peat and peaty clay. Coring 78 has been sampled for pollen analysis (Fig. 9).

Zone 1 (135-127 cm; clay) is characterised by relatively high non-arboreal pollen percentages and low Betula values. The presence of Juniperus, Empetrum, Plantago, Thalictrum and Asteraceae indicates cold and dry conditions and rather open vegetation that can be attributed to the Older Dryas (PAZ 1c). The presence of Alnus and Quercus can be explained by deposition of clastic sediment in the channel, derived from erosion of older deposits in the catchment.

Zone 2 (127-105 cm; humic clay and gyttja) shows an increase of Betula up to $60 \%$ and a decrease of grasses and heliophilous herbs like Helianthemum, Plantago and Empetrum. Wetland herbs and aquatics increase, indicating warmer and wetter conditions or higher lake levels that can be attributed to the Allerød (PAZ 2a). At the top of this zone Pinus increases slightly and aquatics decrease, which might be attributed to the Pinus-phase of the Allerød (PAZ 2b). The low pine values, compared to diagram Karken, can be related to sitespecific conditions as site Geraerds is located more in the central wetter part of the palaeovalley. Pinus probably colonised the higher, freely drained surface of terrace level A (Hoek, 2000).

Zone 3 (105-86 cm; clay) is characterised by a decrease in arboreal pollen, probably due to climate cooling. Poaceae show an increase and heliophilous herbs and Juniperus are present, indicating rather open vegetation that can be attributed to the Younger Dryas (PAZ 3). Wetland herbs and aquatics show a maximum in this interval, indicating wetter conditions that may be related to channel reactivation, flooding and deposition of clastic material in this interval.

Zone 4 ( $86-76 \mathrm{~cm}$; clay and peat) shows a strong increase in arboreal pollen and decrease in Poaceae and heliophilous herbs. Corylus content is high and Quercus is present in low values which is characteristic for the Boreal (PAZ 5). As in the diagram Karken, the Preboreal pollen zone is not observed. Traces of soil formation in the top of the clay and high values of 
indeterminable pollen indicate a water-level drop in the Geraerds palaeochannel, probably related to incision of the Roer at the Late-glacial to Early Holocene transition.

\section{Cross section Haaserdriesch}

Cross section Haaserdriesch is situated in the central part of level B (Fig. 5). The channel lag is found slightly below $29 \mathrm{~m}$ a.s.l. and the channel fill is thicker than in the previous cross sections, so a more complete succession might be present (Fig. 7). Gravelly coarse sand of the channel lag deposit is overlain by medium-grained channel and pointbar sands that formed during the active stage of the channel. Sandy loams were deposited at the margins of the channel (cores 98, 95) during the first stage of channel abandonment, thereby decreasing the width of the channel. In the remaining channel (core 97), carbonate-rich gyttja (lake marl) was deposited, abruptly followed by clay and moss peat. Unlike Karken and Geraerds, no signs of soil formation have been observed in the top of the clay. The upper part of the fill consists of clay, peat and loam. Coring 97 has been sampled for pollen analysis (Fig. 10).

Zone 1 (258-245 cm; clayey gyttja) is characterised by low tree values and high percentages of Poaceae (40\%) and heliophilous herbs (Asteraceae). The presence of Helianthemum, Plantago and Rumex in the regional vegetation indicates unstable soil conditions and treeless vegetation that can be associated with the cold and dry Older Dryas (PAZ 1c). The high value of aquatics in the local vegetation, mainly Potamogeton, demonstrates the presence of lake conditions in the former channel. The clayey character of the gyttja can be explained by occasional flooding of the palaeochannel shortly after its abandonment.

Zone $2(245-195 \mathrm{~cm}$; calcareous gyttja) shows a strong increase in Salix up to $40 \%$ and a decrease in heliophilous herbs and Poaceae. Betula values are low, probably due to the local presence of Salix. Despite the low Betula values, this interval can be attributed to the Allerød (PAZ 2), also because of the high calcium carbonate content pointing to higher temperature conditions. The drop in Myriophyllum during this zone can be attributed to the general lowering of the groundwater table at the transition from PAZ $2 \mathrm{a}$ to $2 \mathrm{~b}$ (Hoek 1997b). However, the Allerød Pinus-phase (PAZ 2b) is absent in the diagram, possibly due to the nearby presence of dense Salix stands colonising the channel margins and filtering out the Pinus pollen.

Zone 3 (195-158 cm; clay) starts with a brief increase in Poaceae, while Betula decreases. Non-arboreal pollen, like Artemisia, Potentilla, Chenopodiaceae, Asteraceae, Helianthemum and Rumex, increase, indicating unstable soils and open vegetation. The presence of Alnus and Quercus can be explained by reworking, which is supported by the siliciclastic character of the sediment. The presence of Empetrum and Ephedra is characteristic for the Younger Dryas (PAZ 3).

Zone 4 (158-140 cm; gyttja and moss peat) shows a Juniper peak and sudden increase of Filipendula, followed by a strong increase in Betula up to $80 \%$, indicating the start of the Holocene (Preboreal, PAZ 4). The presence of Typha latifolia indicates summer temperatures above $13^{\circ} \mathrm{C}$ (Isarin \& Bohncke, 1999). The transition from gyttja to peat and increase of the wetland herbs (Cyperaceae) can be explained by a decrease in water depth and hydroseral succession. In contrast to Karken and Geraerds, where a hiatus was observed in the Preboreal, at the Haaserdriesch site the Preboreal is present, probably because of the larger channel depth. The upper part of zone 4 (140-125 cm; clay) shows an increase of Pinus, the first occurrence of Corylus and low upland herb values. This zone can be interpreted as the early Boreal (PAZ 5).

\section{Cross sections Kitscherholz and Kitscherholz $b$}

Cross sections Kitscherholz and Kitscherholz $\mathrm{b}$ are located in the axis and lowest part of the palaeovalley (level B) and therefore might contain the youngest sedimentary succession (Fig. 5). At the base of the cross section around $29 \mathrm{~m}$ a.s.l. gravelly coarse sand and medium sands occur, which were deposited on the channel bed and possibly as pointbars (Fig. 7). Loams and fine sand were deposited at the margins of the channel under low flow velocities, and the wet cross-sectional area of the channel therefore decreased during or shortly after the abandonment (cores 99, 101, 46, 48). Following the final abandonment clayey gyttja, gyttja and oxidised peat were deposited in the remaining small channel under standing water conditions (cores $100,45,47$ ). The peat is overlain with a sharp boundary by sandy clay, suggesting channel reactivation by floods with suspended material. Peaty clay, loam and sandy loam in the upper part possibly reflect young brook deposits. Coring 100 has been sampled for pollen analysis, but the sampling interval is large, hampering the biostratigraphic zonation (Fig. 11).

Zone 1 (148-140 cm; clay) has low Betula values and high values of Artemisia, Thalictrum and Asteraceae. The presence of Juniperus might indicate the final stage of the Younger Dryas or the Late-glacial to Holocene transition.

Zone 2 (140-115 cm; gyttja and peat) is characterised by high Betula values (40-60\%), Pinus (10-20\%) and Poaceae and this zone could reflect the Preboreal (PAZ 4). The changes in the Poaceae curve might reflect the climate oscillation of the Rammelbeek phase.

Zone 3 (115-112 cm; clay) shows the presence of Corylus, indicating the start of the Boreal. 